\title{
Review \\ Multi-Objective Optimization Models to Design a Responsive Built Environment: A Synthetic Review
}

\author{
Mattia Manni * and Andrea Nicolini (D) \\ Department of Engineering, University of Perugia, 06125 Perugia, Italy; andrea.nicolini@unipg.it \\ * Correspondence: mattia.manni@unipg.it; Tel.: +39-075-585-3714
}

\begin{abstract}
A synthetic review of the application of multi-objective optimization models to the design of climate-responsive buildings and neighbourhoods is carried out. The review focused on the software utilized during both simulation and optimization stages, as well as on the objective functions and the design variables. The hereby work aims at identifying knowledge gaps and future trends in the research field of automation in the design of buildings. Around 140 scientific journal articles, published between 2014 and 2021, were selected from Scopus and Web of Science databases. A three-step selection process was applied to refine the search terms and to discard works investigating mechanical, structural, and seismic topics. Meta-analysis of the results highlighted that multiobjective optimization models are widely exploited for (i) enhancing building's energy efficiency, (ii) improving thermal and (iii) visual comfort, minimizing (iv) life-cycle costs, and (v) emissions. Reviewed workflows demonstrated to be suitable for exploring different design alternatives for building envelope, systems layout, and occupancy patterns. Nonetheless, there are still some aspects that need to be further enhanced to fully enable their potential such as the ability to operate at multiple temporal and spatial scales and the possibility of exploring strategies based on sector coupling to improve a building's energy efficiency.
\end{abstract}

check for updates

Citation: Manni, M.; Nicolini, A. Multi-Objective Optimization Models to Design a Responsive Built Environment: A Synthetic Review. Energies 2022, 15, 486. https:// doi.org/10.3390/en15020486

Academic Editor: Fitsum Tariku

Received: 22 November 2021

Accepted: 5 January 2022

Published: 11 January 2022

Publisher's Note: MDPI stays neutral with regard to jurisdictional claims in published maps and institutional affiliations.

Copyright: (c) 2022 by the authors. Licensee MDPI, Basel, Switzerland. This article is an open access article distributed under the terms and conditions of the Creative Commons Attribution (CC BY) license (https:// creativecommons.org/licenses/by/ $4.0 /)$.
Keywords: multi-objective optimization; genetic algorithm; parametric modelling; integrated building design

\section{Introduction}

Construction of buildings and infrastructure is a significant contributor to global warming, due to the high involvement of machineries, land use change, and material consumption. More than six tenths of the global energy consumption and around four tenths of greenhouse gases (GHG) emissions can be attributed to the building sector [1]. Following this, several countries such as Japan, Norway, and Sweden have adopted zeroenergy building (ZEB) goals and policies, whereas many others such as Morocco, Germany, and Italy have established thermal regulations for buildings that identify minimum energy performance levels for new constructions [2]. Within this framework, the building energy efficiency topic has aroused the interest of several researchers around the world. Strategies to improve the energy performance of buildings have been proposed which apply passive (i.e., building shape and orientation, envelope properties, natural ventilation) or active systems and technologies (i.e., heating, ventilation and air conditioning system, photovoltaic systems). However, building performance covers many targets in addition to energy efficiency such as indoor visual and thermal comfort, and environmental and economic sustainability. When improving building performance, these aspects can conflict with each other [3] and it is necessary to seek a balance among them. Exploring all the alternatives to find an efficient design is a time-consuming task; therefore, many authors developed simulation-based optimization workflows which couple building performance simulation (BPS) tools with optimization algorithms [4]. Since multiple variables and objectives occur in complex optimization problems such as the integrated building design, 
non-gradient-based algorithms such as genetic algorithms (GAs) are exploited to solve these discontinuous objective functions [5]. Such multi-objective optimization (MOO) models are mostly applied during the early stage of the design process when even the less accurate analysis (building components and materials properties are not defined in detail at this stage) can have a significant impact.

Building performance optimization (BPO) can be considered as a $\mathrm{MOO}$ problem and the solution consists of the trade-off between the different identified objectives. However, when it comes to mutually conflicting objectives, a set of non-dominated solutions results, which constitute the Pareto front. The Pareto front grouped the optimal Pareto solutions, and it is $n$-dimensional, where $n$ is the number of objective functions evaluated. Evolutionary optimization algorithms such as multi-objective particle-swarm optimization (MOPSO), strength Pareto evolutionary algorithm (SPEA2), and non-sorting genetic algorithm (NSGA-II) are widely used to solve multi-objective problems. In particular, the NSGA-II turned out to be the most appreciated when it comes to BPO due to its efficient sorting of non-dominated solutions which ease the convergence, and also its capability of well distributing Pareto-optimal solutions along the Pareto front [6,7].

Despite the proven advantages of using GAs, the optimization process tends to be difficult when BPS requires a lot of time (a large building or too many objective functions are considered). To overcome this issue, metamodels were introduced to predict building performance, after being appositely trained, with a lower computational time [8]. Metamodels consist of, literally, a model of a model which permits studying correlations between inputs and outputs observed in a more complex model [9]. When applied to BPS, the artificial neural network (ANN) metamodels are trained on the basis of a representative sample of results from building performance analyses (outputs) for various sets of design variables (inputs). Then, ANN metamodels are generally coupled to GAs in order to conduct BPO.

The integrated building design has been widely investigated over the last decades. The introduction of metamodels enabled solving more complex MOO problems characterized by numerous objective functions or large building case studies, with a relatively low computational time $[10,11]$. Within this framework, the present work aims at reviewing the state of the art concerning MOO models applied to the integrated building design for identifying knowledge gaps and future trends in this research field. The review study focuses on (i) exploited optimization tools and the respective programming languages, (ii) objective functions and their combinations, (iii) explored design variables, and (iv) the capability of evaluating long-term impacts. Outcomes will provide a background for future research works dealing with BPO by contributing to the definition of the most effective MOO workflow to be followed.

The paper is arranged into four sections: an introductive section (Section 1), which provides the background about the topic of this synthetic review; the Method (Section 2), in which the methodology followed is outlined; the Results and discussion (Section 3) which is divided into three Sections about the general description of the selected journal articles (Section 3.1), reviewed MOO models (Section 3.2), and identified knowledge gaps and future trends (Section 3.3); the conclusive section (Section 4), where the main achievements are reported in brief.

\section{Method}

A synthetic review was conducted to investigate the applications of MOO models to integrated building design. Scientific journal articles that focused on the optimization of building and neighbourhoods' performances (i.e., energy and environmental impact, thermal and visual comfort, solar accessibility) were reviewed. Two databases were considered as the sources to find these journal articles: Scopus and Web of Science (WoS). These were chosen as they return literature from highly reliable sources with wide geographic coverage. Identical search terms were used in both the databases, whereas the research to acquire relevant journal articles was conducted in three steps. Initially, the "building", "multiobjective" and "optim" terms were searched in titles, abstracts, and keywords from 
papers collected in the two databases (step one). The Boolean Operator "and" was used to connect the search fields in all databases to ensure consistency of searches. The chosen search terms were found in around 2690 and 4180 journal articles in Scopus and WoS, respectively. The order of the terms within a search field was found to not alter the returned literature: for example, "building multiobjective optimization" and "multiobjective optimization building" returned the same publications. However, this search was deemed ineffective as it returned a wide range of literature with topics not pertaining to the exploitation of MOO models in the integrated building design. To narrow the results, the terms "design" and "architectur" were used together with "building", "multiobjective", and "optimiz" to acquire a focused set of literature for reviewing (step two). Search terms were refined with the help of the VOS Visualizer tool with the aim of providing a view of how MOO models are used throughout the building design process with an emphasis on architectural applications. Indeed, this machine learning-based tool ranks the words in the titles, abstracts, and authors' keywords of the collected scientific journal articles and then applies clustering models to classify the most used words in groups (Figure 1). The consequent density visualization provided a quick overview of the main areas in the bibliometric network highlighting the presence of journal articles about optimization of mechanical components of systems and plants (i.e., turbines, engines, compressors). To further narrow the results, the typology of the scientific journal articles to be included in the present review was defined as "article", thus excluding conference proceedings, books, and other review studies (step three).

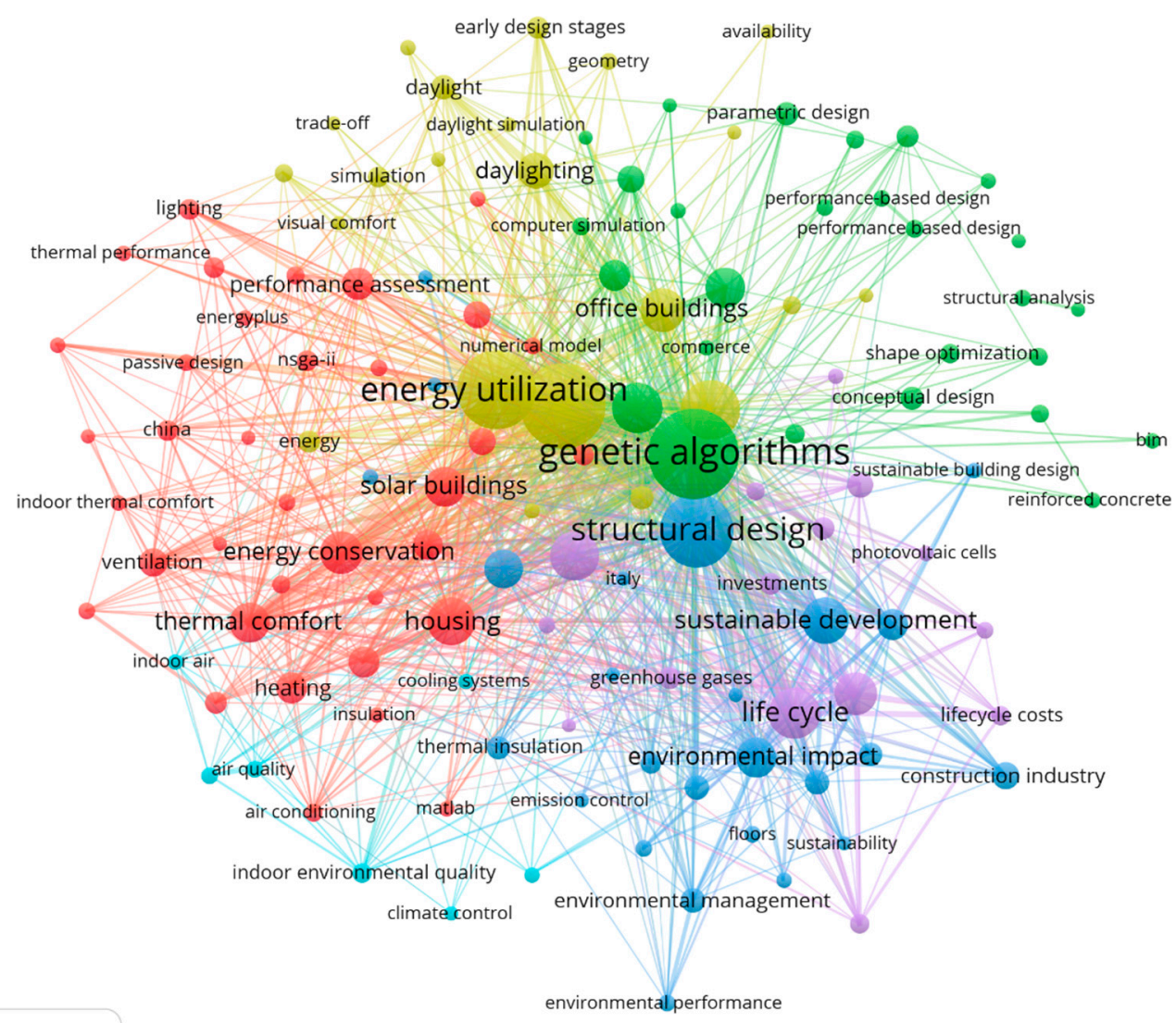

VOSviewer

Figure 1. Density visualization of words in the title, abstract, and authors' keywords from the journal articles selected at the end of step two. The words included in the search (i.e., "multiobjective", "design") were excluded from the figure. 
The term "multiobjective" was chosen to capture the optimization studies which handle more than one objective function in their approaches. The use of "building design" returned more specific literature when compared with the results from the "building" search term, thus the former was used for this study. The "optim*" search term was chosen to capture "optimization", "optimized", and "optimizing" in relevant articles. The review includes articles published and available online between 2014 and the end of 2021. The search returned 367 unique journal articles, which went through a further screening process. The abstracts of all downloaded papers were reviewed to assess whether the papers had a "structural and seismic", "energy and comfort", "environment and economy" or "other" focus. Papers classified as "structural and seismic" discussed the optimization of structural properties and seismic resistance of buildings; "energy and comfort" focused on minimizing energy demand while enhancing visual and thermal comfort; "environment and economy" focused on life-cycle analyses concerning building's carbon intensity and costs; and "other" did not focus on the built environment or had a scope not relevant to the other categories such as systems and plant sizing. Following the screening process, 141 journal articles that were classified with "energy and comfort" and "environment and economy" focuses were reviewed in detail.

\section{Results and Discussion}

\subsection{General Description of the Selected Journal Articles}

A tabular review is reported in the Appendix A section (Table A1) in which the year of publication, the case study location, the investigated building typology, the objective functions, the temporal horizon of the impact assessment, the exploited simulation engine, the applied optimization method, and the optimization variables are reported for each reviewed journal article.

The temporal distribution of the reviewed research studies is reported in Figure 2. The number of published journal articles concerning the application of MOO model to integrated building design was increased by ten times over the last seven years, from 3 journal articles in 2014 to 37 journal articles in 2021.

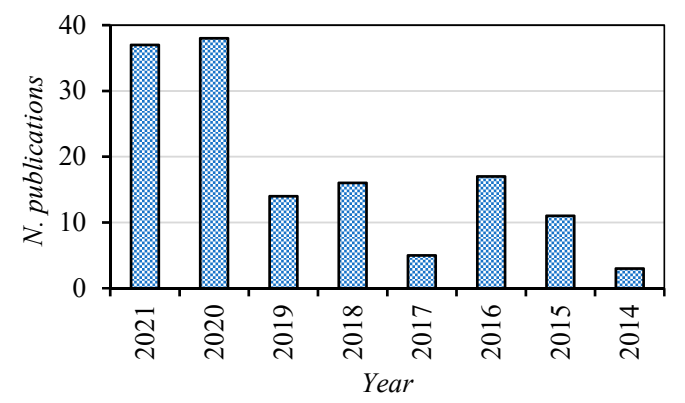

Figure 2. Temporal distribution of the reviewed journal articles.

Most of the investigated case studies were located in China (26), Italy (12), and Iran (10) (Figure 3). Alongside these, up to 11 journal articles evaluated the effectiveness of the proposed MOO models at various latitudes through comparative analyses ("miscellaneous" category). Less than 10 publications were found for the other locations.

In the reviewed journal articles, the MOO models were exploited to BPO at various scales ranging from the neighborhood scale (3) to the test room scale (7) (Figure 4). However, such workflows were mainly applied to design highly effective configurations of residential (62), office (36), and educational buildings (17). Fewer studies focus on commercial (2), sport (2), and miscellaneous buildings (3), whereas up to nine publications dealt with other building typologies such as tourist centers and community spaces. 


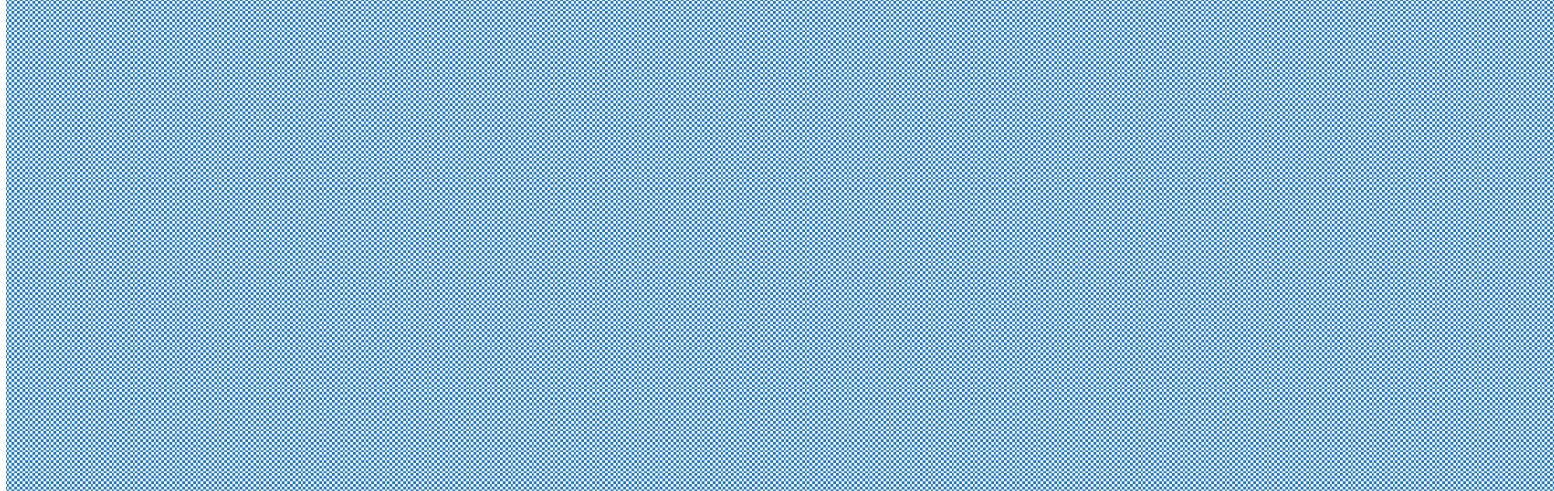

Figure 3. Spatial distribution of the case studies investigated in the reviewed journal articles. Studies applying the MOO workflow to various latitudes are clustered in the "miscellaneous" category.

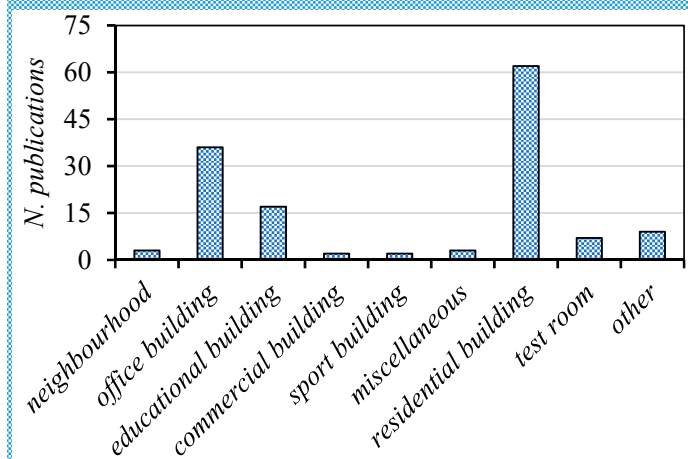

Figure 4. Case study typologies assessed in the reviewed journal articles. The "other" category includes other building typologies such as public buildings and tourist centers.

Implemented GAs were mostly used for solving optimization problems with two (92) and three objective functions (43). Only six publications proposed the simultaneous optimization of more than four variables. Enhancing building's energy performance levels (EN category in Figure 5) was included among the research goals of more than one hundred studies (115), whereas guaranteeing adequate thermal and visual comfort conditions (THERM and DAYL categories in Figure 5) was searched by authors of 73 and 57 journal articles, respectively (Figure 5). Finally, up to 53 studies aimed at minimizing life-cycle costs and other economical parameters (LCC category in Figure 5), whereas only 25 studies evaluated life-cycle emissions (LCA category in Figure 5).

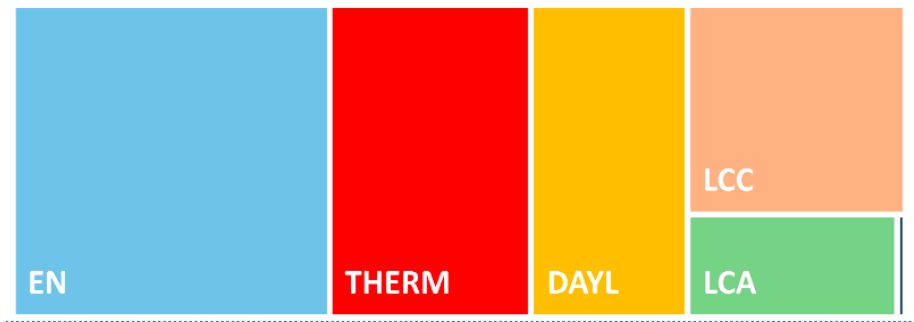

Figure 5. Objective functions evaluated in the reviewed journal articles. A larger area corresponds to a higher number of works that optimized that function.

The analysis of the possible combinations of two objective functions (Table 1) highlighted that the minimization of energy consumption was carried out along with thermal comfort optimization in 60 studies, and with visual comfort optimization in 45 studies. Furthermore, energy-related objective functions were solved together with life-cycle cost minimization in 37 studies. 
Table 1. The number of publications per each couple of objective functions. Color transparency is inversely proportional to the number of publications. The white color corresponds to zero, whereas the red color corresponds to the highest amount (60).

\begin{tabular}{|c|c|c|c|c|c|c|}
\hline$\underset{U}{U}$ & 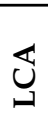 & $Z_{\text {III }}$ & 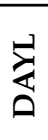 & $\frac{\mathrm{Z}}{\mathrm{z}}$ & 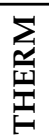 & \\
\hline \multirow[t]{6}{*}{53} & 18 & 37 & 9 & 0 & 26 & LCC \\
\hline & 25 & 13 & 5 & 0 & 10 & LCA \\
\hline & & 115 & 45 & 0 & 60 & EN \\
\hline & & & 57 & 0 & 24 & DAYL \\
\hline & & & & 1 & 0 & WIND \\
\hline & & & & & 73 & THERM \\
\hline
\end{tabular}

To solve the aforementioned objective functions, the main simulation engines which were found to be used in BPS are TRNSYS and EnergyPlus for thermal and energy analyses, and Radiance for daylight and solar radiation assessment. These were utilized through different tools such as DIVA, Ladybug and Honeybee for Grasshopper, DesignBuilder, and Autodesk REVIT. Moreover, life-cycle cost (LCC) analyses were conducted through numerical models implemented in Visual Basic for Applications (VBA) and MATLAB environment, whereas life-cycle assessment (LCA) was mainly performed by SimaPro software.

Python, MATLAB, and Java were the most utilized programming languages to develop optimization algorithms (Figure 6). Python-based tools such as Opossum, Galapagos, Colibrì, and Octopus were utilized within the Grasshopper environment. Similarly, jEPlus and Optimo (both programmed in Python) were coupled to EnergyPlus and Dynamo, respectively. MATLAB was exploited to perform optimization analyses together with TRNSYS, ANSYS, and EnergyPlus software, in 38 studies. Finally, GenOpt tool from Java was integrated with TRNSYS and EnergyPlus in 5 studies. Despite the programming language, the NSGA-II was the GA applied by almost all of the authors.

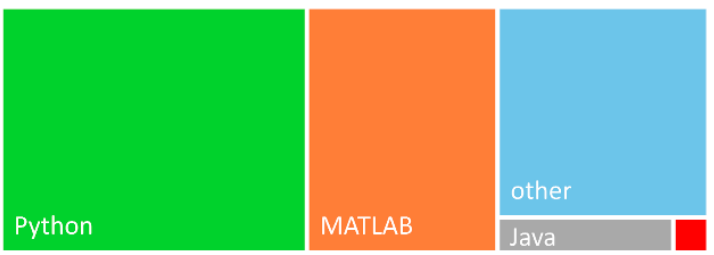

Figure 6. Programming languages utilized to write the MOO algorithms in the reviewed journal articles. A larger area corresponds to a higher number of algorithms based on that programming language. The "other" category also includes those journal articles which did not declare the programming language.

Almost the totality of the reviewed studies performed multi-objective optimization analyses over short-term temporal horizons. It is worth highlighting that the authors of three studies carried out BPS analyses throughout the building's life cycle, thus taking into account both current and future climate scenarios.

When it comes to the optimization variables, the reviewed MOO models were capable of exploring different design solutions or strategies for the building's orientation (40), window-to-wall ratio (WWR) (71), window typologies (84), building's shape (21), insulation properties of the building envelope (86), infiltration rate (18), heating system layout (34), shading devices (40), exploitation of natural ventilation (20), exploitation of renewable energy sources (RESs) (19), lighting appliances (10), and occupancy pattern (8) (Table 2). Most of the studies optimized from one to five independent variables (125), whereas only 16 studies were handling more than five variables. In particular, geometrical and physical properties of the building envelope such as orientation, shape, the extension of the glazed surface, shading solutions, and thermal insulation level of both opaque and transparent 
components were optimized together. Among these, the window typology was generally optimized along with the insulation properties of the outer walls/rooftop (68) or the WWR (57), whereas the WWR was mostly optimized together with the envelope insulation (52).

Table 2. The number of publications per each couple of optimization variables (i.e., there are 32 journal articles that optimize WWR and orientation at the same time). Color transparency is inversely proportional to the number of publications. The white color corresponds to zero, whereas the red color corresponds to the highest amount (68).

\begin{tabular}{|c|c|c|c|c|c|c|c|c|c|c|c|c|}
\hline & $\frac{\mathfrak{s}}{3}$ & 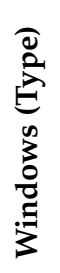 & 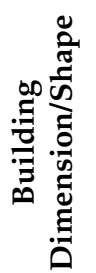 & 总. & 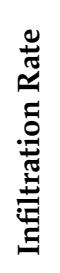 & 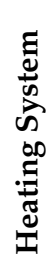 & 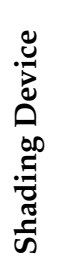 & 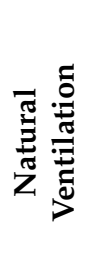 & 笠 & 雚 & 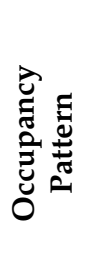 & \\
\hline \multirow[t]{12}{*}{40} & 32 & 30 & 11 & 33 & 8 & 8 & 15 & 5 & 2 & 3 & 1 & Orientation \\
\hline & 71 & 57 & 13 & 52 & 12 & 13 & 28 & 10 & 3 & 5 & 3 & WWR \\
\hline & & 84 & 7 & 68 & 14 & 20 & 30 & 14 & 10 & 7 & 4 & Windows (type) \\
\hline & & & 21 & 9 & 0 & 0 & 3 & 1 & 1 & 0 & 0 & $\begin{array}{c}\text { Building } \\
\text { dimension/shape }\end{array}$ \\
\hline & & & & 86 & 18 & 25 & 27 & 11 & 14 & 9 & 5 & Envelope insulation \\
\hline & & & & & 18 & 4 & 5 & 3 & 1 & 2 & 2 & Infiltration rate \\
\hline & & & & & & 34 & 8 & 7 & 7 & 6 & 4 & Heating system \\
\hline & & & & & & & 40 & 9 & 2 & 3 & 0 & Shading device \\
\hline & & & & & & & & 20 & 0 & 4 & 0 & Natural ventilation \\
\hline & & & & & & & & & 19 & 0 & 0 & RES \\
\hline & & & & & & & & & & 10 & 3 & Lighting appliances \\
\hline & & & & & & & & & & & 8 & Occupancy pattern \\
\hline
\end{tabular}

\subsection{Multi-Objective Optimization Workflows}

\subsubsection{Python-Based Workflows}

Python programming language was found to be the most utilized in the reviewed journal articles. Python libraries such as Numpy and Pandas exist, which enable solving MOO problems [12]. Moreover, some Python-based optimization tools can be easily coupled to simulation engines such as Radiance and EnergyPlus. Numerous studies included Octopus [13-15] and other optimization tools from Grasshopper such as Galapagos [16,17] and Colibrì [3,18] into their workflows (Figure 7). Zhuang et al. [19] proposed a performanceintegrated BIM framework for building life-cycle energy efficiency and carbon optimization (Table 3). Ladybug and Honeybee were coupled to Octopus to improve indoor environmental quality and reduce LCCs of an education building case study. Similar approaches were followed by Zani et al. [20] for designing an educational building in Italy, by Lobaccaro et al. [21] for achieving the zero-emission target in a residential building in Norway, and by Pilechiha et al. [22] for exploring highly energy effective configurations of an office building in Iran (Table 3). Through its plug-ins, Grasshopper allowed for investigating different aspects of buildings, thus enabling a high number of objective functions. For instance, the GA from Negendahl and Nielsen [23] was capable to handle up to four objective functions: building energy use, capital cost, daylight distribution, and thermal indoor environment.

Several research studies developed Python-based algorithms linking EnergyPlus and TRNSYS simulation tools with jEPlus and Multi-Objective Building Optimization (MOBO) plug-ins, respectively [24-26]. In particular, Pajek and Košir [26] aimed at outlining the implications of passive design measures on the energy use of single-family residential buildings under European representative climates. Results demonstrated that it is difficult to neutralise the projected climate change effects on buildings' energy use, even when 
applying the best performing combination of passive design measures. In the findings of Abdou et al. [2], the MOBO tool was applied to the exploration of design alternatives for retrofitting of an existing residential building, with the overall goal of meeting the zero-energy balance. The workflow permitted us to achieve significant energy savings in different Moroccan regions.

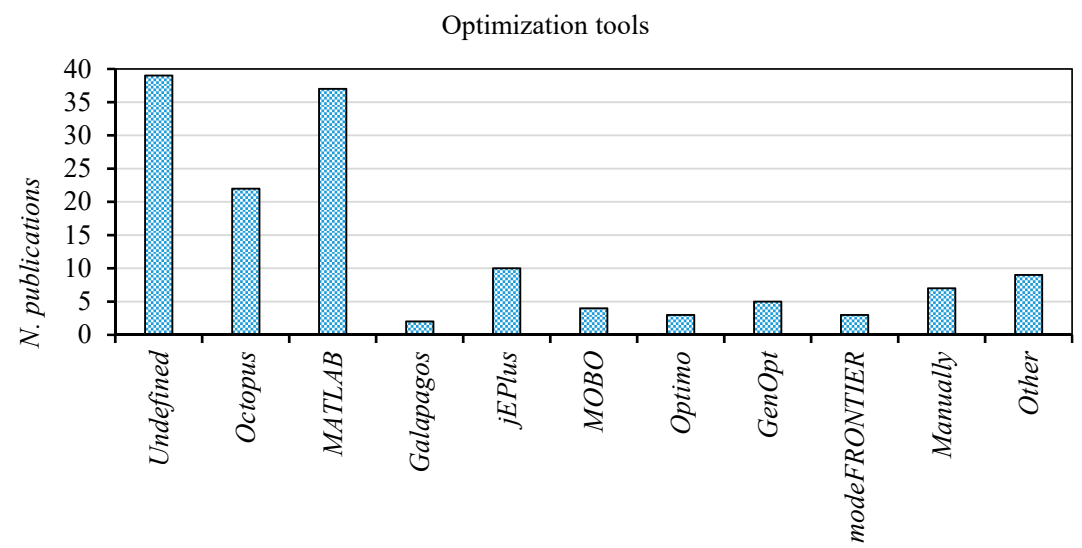

Figure 7. Number of publications for each optimization engine exploited in the MOO models.

Finally, the Optimo tool was utilized within the Dynamo environment to perform optimizations about energy demand, thermal and visual comfort, and solar accessibility [27-29]. Such workflows, which showed a lower number of variables if compared with the others, were mainly exploited to identify high effective configurations of a building's envelope.

As reported in Figure 8a, up to 50 publications describe MOO models capable of optimizing the building energy performance, whereas only 18 and 12 publications minimize life-cycle costs and emissions, respectively. Alongside these, solar accessibility (30) and thermal comfort (30) were included among the objective functions of 60 publications.
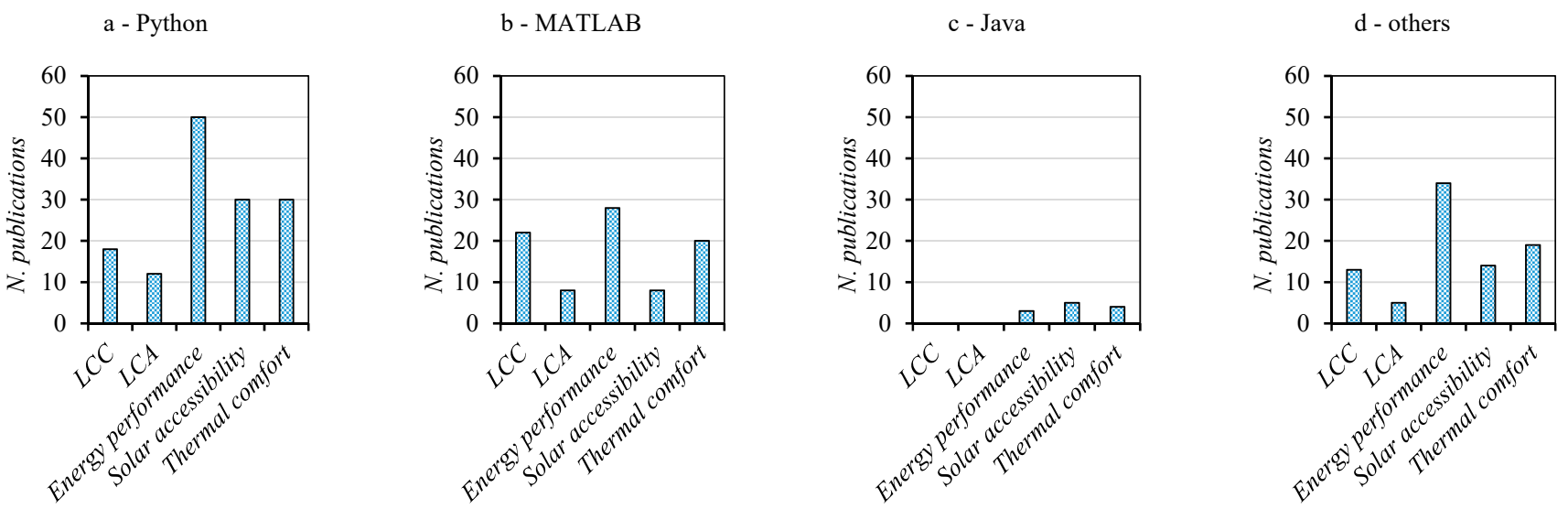

Figure 8. Number of publications for each objective function. Results are presented according to the used programming language: (a) Python, (b) MATLAB, (c) Jave, and (d) others.

\subsubsection{MATLAB-Based Workflows}

Around 40 research studies presented workflows based on MATLAB. These were using MATLAB's functions such as gamultiobj to identify the Pareto front (Figure 7). EnergyPlus, TRNSYS, and DAYSIM were the most exploited simulation engines to perform energy and solar analysis as well as to evaluate thermal and visual comfort conditions [30-32]. Alongside these, SimaPro software was also integrated into the MOO model developed by Islam et al. [33] to minimize life-cycle emissions and costs. 
Table 3. Tabular review of journal articles about Python-based MOO workflows.

\begin{tabular}{|c|c|c|c|c|c|c|c|c|c|c|c|c|c|c|c|c|c|c|c|c|c|}
\hline \multirow[b]{2}{*}{$\stackrel{\mathscr{J}}{\simeq}$} & \multirow[b]{2}{*}{ ‡્ર } & \multicolumn{5}{|c|}{ Optimized Parameters } & \multirow[b]{2}{*}{ 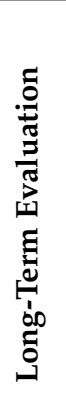 } & \multirow[b]{2}{*}{ 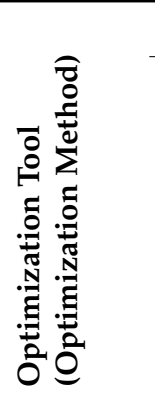 } & \multicolumn{13}{|c|}{ Parameters } \\
\hline & & $\underset{U}{U}$ & $\underset{త}{త}$ & 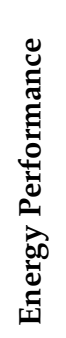 & 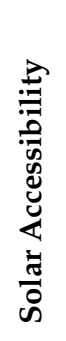 & 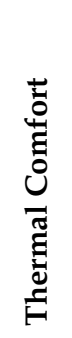 & & & & $\frac{3}{3}$ & 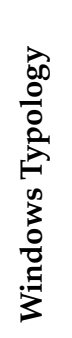 & 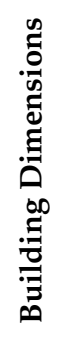 & 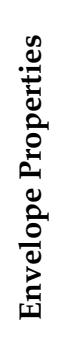 & 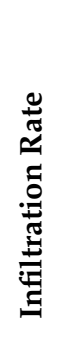 & 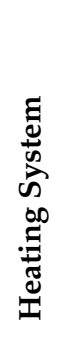 & 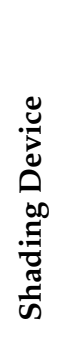 & 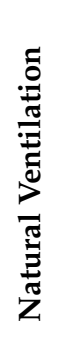 & 望 & 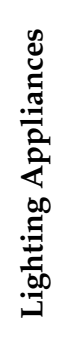 & 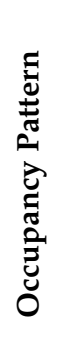 & ڤั) \\
\hline [27] & 2015 & & & $\mathbf{x}$ & $\mathbf{x}$ & & $\mathbf{N}$ & Optimo & & $x$ & $\mathbf{x}$ & & & & & & & & & & \\
\hline [23] & 2015 & $\mathbf{x}$ & & $\mathbf{x}$ & $\mathbf{x}$ & & $\mathbf{N}$ & Octopus & & & & $\mathbf{x}$ & & & & & & & & & \\
\hline [24] & 2016 & $\mathbf{x}$ & $\mathbf{x}$ & $\mathbf{x}$ & & & $\mathbf{N}$ & jEPlus & & & & & $x$ & & & & & & & & \\
\hline [20] & 2017 & & & $\mathbf{x}$ & & & $\mathbf{N}$ & Octopus & & & & & & & & & & & & $\mathbf{x}$ & \\
\hline [17] & 2017 & $x$ & & $x$ & & & $\mathbf{N}$ & Galapagos & & & $\mathbf{x}$ & & $\mathbf{x}$ & & & $\mathbf{x}$ & & & & & \\
\hline [25] & 2018 & $\mathbf{x}$ & & $\mathbf{x}$ & & & $\mathbf{N}$ & $\begin{array}{c}\text { MOBO } \\
\text { tool }\end{array}$ & & $\mathbf{x}$ & $\mathbf{x}$ & & $\mathbf{x}$ & & & & & & & & \\
\hline [21] & 2018 & & $\mathbf{x}$ & & $\mathbf{x}$ & & $\mathbf{N}$ & Octopus & $\mathbf{x}$ & $\mathbf{x}$ & & $\mathbf{x}$ & $\mathbf{x}$ & & & & & & & & \\
\hline [16] & 2020 & & & $\mathbf{x}$ & & & $\mathbf{N}$ & Galapagos & & & & & $\mathbf{x}$ & $\mathbf{x}$ & & & & & $\mathbf{x}$ & $\mathbf{x}$ & \\
\hline [15] & 2020 & & & $\mathbf{x}$ & $\mathbf{x}$ & & $\mathbf{N}$ & Octopus & & & & & & & & $\mathbf{x}$ & & & & & \\
\hline [29] & 2020 & & & $\mathbf{x}$ & $x$ & & $\mathbf{N}$ & Optimo & & $\mathbf{x}$ & $\mathbf{x}$ & & & & & & & & & & \\
\hline [28] & 2020 & & $\mathbf{x}$ & $\mathbf{x}$ & & & $\mathbf{N}$ & Optimo & & & & & $\mathbf{x}$ & & & & & & & & \\
\hline [22] & 2020 & & & $\mathbf{x}$ & $\mathbf{x}$ & & $\mathbf{N}$ & Octopus & & $\mathbf{x}$ & & $\mathbf{x}$ & & & & & & & & & \\
\hline [2] & 2021 & $\mathbf{x}$ & & $x$ & & & $\mathbf{N}$ & МОВО & $\mathbf{x}$ & $\mathbf{x}$ & $x$ & & $\mathbf{x}$ & $\mathbf{x}$ & & & & & & & \\
\hline [12] & 2021 & $\mathbf{x}$ & $\mathbf{x}$ & $\mathbf{x}$ & & & $\mathbf{N}$ & Python & & & & & $x$ & & $\mathbf{x}$ & & & & & & \\
\hline [26] & 2021 & & & $\mathbf{x}$ & & & $\mathbf{Y}$ & jEPlus & & $x$ & $x$ & $x$ & $x$ & & & & $\mathbf{x}$ & & & & \\
\hline [18] & 2021 & & & $\mathbf{x}$ & $\mathbf{x}$ & & $\mathbf{N}$ & $\begin{array}{l}\text { Colibri, } \\
\text { Octopus }\end{array}$ & & $x$ & $\mathbf{x}$ & & & & & & & & & & \\
\hline [19] & 2021 & $x$ & & $\mathbf{x}$ & & & $\mathbf{N}$ & Octopus & & & $\mathbf{x}$ & & $x$ & & & & & & & & \\
\hline [3] & 2021 & & & $\mathbf{x}$ & $x$ & & $\mathbf{N}$ & Colibri & $\mathbf{x}$ & $x$ & $x$ & $x$ & $\mathbf{x}$ & & & $\mathbf{x}$ & & & & & \\
\hline [14] & 2021 & & & $\mathbf{x}$ & $\mathbf{x}$ & & $\mathbf{N}$ & Octopus & & & & & & & & & & & & & $x$ \\
\hline [13] & 2021 & & & $\mathbf{x}$ & $\mathbf{x}$ & & $\mathbf{N}$ & Octopus & & $\mathbf{x}$ & $\mathbf{x}$ & & & & & & $x$ & & & & \\
\hline
\end{tabular}

In particular, Yong et al. [34] proposed a multi-objective particle swarm algorithm coupled to EnergyPlus to optimize the energy performance of residential buildings (Table 4). Similarly, Ghaderian and Veysi [35] developed an optimization procedure based on combining surrogate models linked to EnergyPlus engine with a GA. This was applied to the enhancement of the building's energy consumption and its occupants' thermal comfort, simultaneously. Pareto's multi-objective approach is applied by Ascione et al. [36] to a neighbourhood case study with the aim of achieving the ZEB standard while ensuring cost-effectiveness.

The MOO models implemented in the MATLAB environment were demonstrated to be suitable for handling a higher number of objective functions. Indeed, three out of the six reviewed journal articles which describe optimization processes involving more than three objective functions were implemented in the MATLAB environment [37-39]. Such workflows enable minimizing investment costs and carbon footprint while enhancing thermal comfort level. Moreover, the approaches proposed by Ascione et al. [38] and 
Chang et al. [39] also improve energy efficiency, whereas the one presented by Karatas and El-Rayes [37] permitted them to efficiently exploit daylight (Table 4).

The MATLAB programming language was also utilized for conducting BPS. The numerical model implemented by Lin et al. [40] allowed of solving a cluster of thermodynamic equations about energy performance and thermal comfort, whereas the numerical model proposed by Ferreira et al. [41] focused on LCC and LCA analyses.

Finally, the three objective functions which were most investigated in MATLAB-based MOO workflows were the energy performance (28), the LCC (22), and the thermal comfort (20) (Figure $8 b$ ). In addition to these, only 16 publications evaluated life-cycle emissions (8) and solar accessibility (8) in combination with other objective functions.

Table 4. Tabular review of journal articles about MATLAB-based MOO workflows.

\begin{tabular}{|c|c|c|c|c|c|c|c|c|c|c|c|c|c|c|c|c|c|c|c|c|}
\hline \multirow[b]{2}{*}{$\stackrel{\ddot{\nu}}{\simeq}$} & \multirow[b]{2}{*}{ ‡્ } & \multicolumn{5}{|c|}{ Optimized Parameters } & \multirow[b]{2}{*}{ 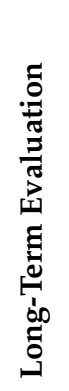 } & \multirow[b]{2}{*}{ 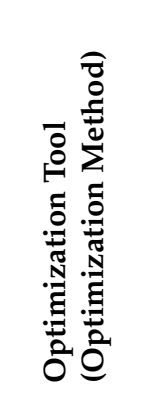 } & \multicolumn{12}{|c|}{ Parameters } \\
\hline & & $\underset{\cup}{U}$ & $\underset{త}{త}$ & 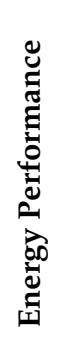 & 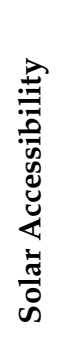 & 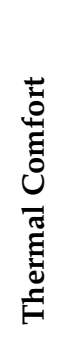 & & & & $\frac{\pi}{3}$ & $\begin{array}{l}00 \\
00 \\
0 \\
0 \\
0 \\
0 \\
0 \\
0 \\
0 \\
0 \\
0 \\
3 \\
3\end{array}$ & 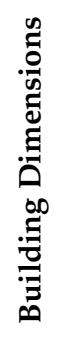 & 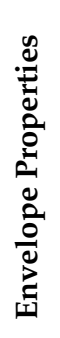 & 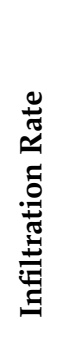 & 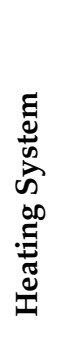 & 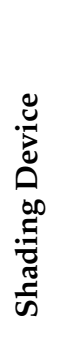 & $\frac{\Xi}{0}$ & 至 & 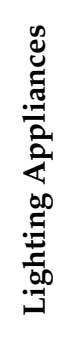 & 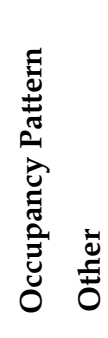 \\
\hline [37] & 2015 & $\mathbf{x}$ & $\mathbf{x}$ & & $\mathbf{x}$ & & $\mathbf{N}$ & $M A T L A B$ & & $\mathbf{x}$ & $\mathbf{x}$ & & $\mathbf{x}$ & & $\mathbf{x}$ & & & & $\mathbf{x}$ & $\mathbf{x}$ \\
\hline [33] & 2015 & $\mathbf{x}$ & $\mathbf{x}$ & & & & $\mathbf{N}$ & LINDO & & & $\mathbf{x}$ & & $\mathbf{x}$ & & & & & & & \\
\hline [30] & 2016 & $\mathbf{x}$ & & $\mathbf{x}$ & & & $\mathbf{N}$ & MATLAB & & & $\mathbf{x}$ & & & & $\mathbf{x}$ & & & & & \\
\hline [31] & 2017 & $\mathbf{x}$ & & $\mathbf{x}$ & & & $\mathbf{N}$ & MATLAB & & & $\mathbf{x}$ & & $\mathbf{x}$ & & $\mathbf{x}$ & & & & & \\
\hline [38] & 2018 & $\mathbf{x}$ & $\mathbf{x}$ & $\mathbf{x}$ & & & $\mathbf{N}$ & $M A T L A B$ & & & $\mathbf{x}$ & & $\mathbf{x}$ & & & & & $\mathbf{x}$ & & \\
\hline [36] & 2020 & $\mathbf{x}$ & & $\mathbf{x}$ & $\mathbf{x}$ & & $\mathbf{N}$ & $M A T L A B$ & & & & & $\mathbf{x}$ & & $\mathbf{x}$ & & & $\mathbf{x}$ & & \\
\hline [34] & 2020 & & & $\mathbf{x}$ & $\mathbf{x}$ & & $\mathbf{N}$ & $M A T L A B$ & $\mathbf{x}$ & $\mathbf{x}$ & $\mathbf{x}$ & & $\mathbf{x}$ & & $\mathbf{x}$ & & & & $\mathbf{x}$ & \\
\hline [39] & 2020 & $\mathbf{x}$ & $\mathbf{x}$ & $x$ & & & $\mathbf{N}$ & MATLAB & & & $\mathbf{x}$ & & $\mathbf{x}$ & & & & & $x$ & & \\
\hline [41] & 2020 & $\mathbf{x}$ & & $x$ & & & $\mathbf{N}$ & $M A T L A B$ & & & & & & & $\mathbf{x}$ & & & $x$ & & \\
\hline [32] & 2020 & & & $\mathbf{x}$ & $\mathbf{x}$ & & $\mathbf{N}$ & MATLAB & & & & & & & & $\mathbf{x}$ & & & & \\
\hline [35] & 2021 & & & $\mathbf{x}$ & & & $\mathbf{N}$ & $M A T L A B$ & & & & & $\mathbf{x}$ & $\mathbf{x}$ & $\mathbf{x}$ & & $\mathbf{x}$ & & & \\
\hline [40] & 2021 & $\mathbf{x}$ & $\mathbf{x}$ & & & & $\mathbf{N}$ & $M A T L A B$ & & $x$ & $\mathbf{x}$ & & $\mathbf{x}$ & & $\mathbf{x}$ & $\mathbf{x}$ & & & & \\
\hline
\end{tabular}

\subsubsection{Java-Based Workflows}

The core of the reviewed Java-based MOO models was represented by the GenOpt tool from the Java GAs package (Figure 7). Such a tool was utilized in five research studies in combination with EnergyPlus, Radiance, and TRNSYS simulation engines [42-44]. Objective functions concern the building's energy demand and solar accessibility, and also thermal comfort and daylight exploitation (Table 5). When it comes to the optimization variables, these workflows explored different envelope configurations by varying WWR, windows' typology, thermal insulation of building envelope, and shading systems.

Carlucci et al. [7] implemented a procedure to support the design of a nearly zeroenergy house in order to minimize thermal and visual discomfort. The non-dominated sorting genetic algorithm, implemented in the GenOpt optimization engine, was used to instruct the EnergyPlus simulation engine. Similarly, the approach proposed by Ameur et al. [43] aimed at optimizing building thermal and lighting energy performance by coupling EnergyPlus and GenOpt tools. 
Figure 8c shows that Java-based MOO workflows were not applied to the optimization of life-cycle costs and emissions. On the contrary, solar accessibility, thermal comfort, and energy performance were investigated in 3,4 , and 5 publications.

Table 5. Tabular review of journal articles about Java-based MOO workflows.

\begin{tabular}{|c|c|c|c|c|c|c|c|c|c|c|c|c|c|c|c|c|c|c|c|c|c|}
\hline \multirow[b]{2}{*}{$\stackrel{\mathscr{\varpi}}{\simeq}$} & \multirow[b]{2}{*}{ ‡ } & \multicolumn{5}{|c|}{ Optimized Parameters } & \multirow[b]{2}{*}{ 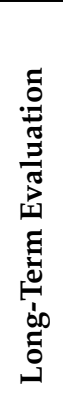 } & \multirow[b]{2}{*}{ 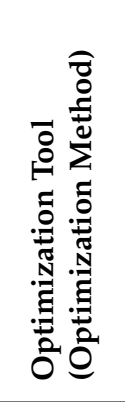 } & \multicolumn{13}{|c|}{ Parameters } \\
\hline & & $\underset{U}{U}$ & $\underset{త}{త}$ & 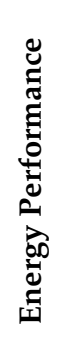 & 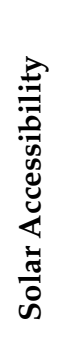 & 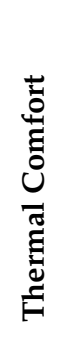 & & & 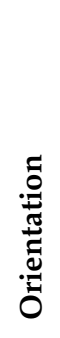 & $\frac{n}{3}$ & 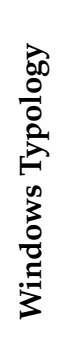 & 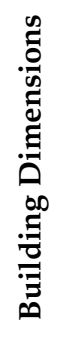 & 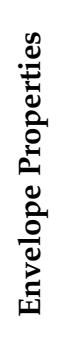 & 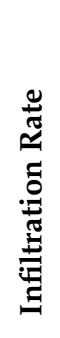 & 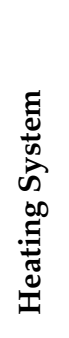 & 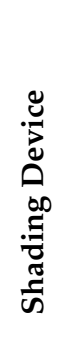 & 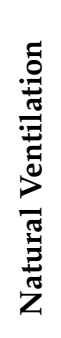 & 足 & 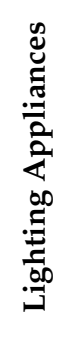 & 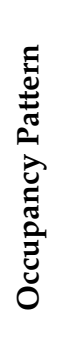 & ثี \\
\hline [42] & 2015 & & & $\mathbf{x}$ & $\mathbf{x}$ & & $\mathbf{N}$ & GenOpt & & $\mathbf{x}$ & $\mathbf{x}$ & & & & & $\mathbf{x}$ & & & & & $\mathbf{x}$ \\
\hline [7] & 2015 & & & & $\mathbf{x}$ & & $\mathbf{N}$ & GenOpt & & & $\mathbf{x}$ & & $\mathbf{x}$ & & & $\mathbf{x}$ & $\mathbf{x}$ & & & & \\
\hline [44] & 2018 & & & $\mathbf{x}$ & $\mathbf{x}$ & & $\mathbf{N}$ & GenOpt & & $\mathbf{x}$ & $\mathbf{x}$ & & $\mathbf{x}$ & & & $\mathbf{x}$ & & & & & \\
\hline [43] & 2020 & & & & $x$ & & $\mathbf{N}$ & GenOpt & & $\mathbf{x}$ & $x$ & & $x$ & & & $\mathbf{x}$ & $\mathbf{x}$ & & & & \\
\hline
\end{tabular}

\subsubsection{Other Workflows}

In this section, all the MOO models which were developed in an unspecified environment or in an environment different from Python, MATLAB, and Java are reported.

The building performance optimization procedures carried out by Si et al. [45] and Giouri et al. [46] were based on ModeFRONTIER software (Figure 7 and Table 6) and they aim to implement integrated decision-making strategies to design high performing buildings. However, Si et al. [45] also exploited a surrogate model developed by an ANN metamodel to reduce the computing time.

A multi-criteria analysis of monocrystalline PV panels mounted on typical southfacing shading devices of office buildings in the Mediterranean region was performed through Visual PROMETHEE software by Stamatakis et al. [47]. A series of objective functions which include PV panels' energy production, buildings' energy efficiency, and users' visual comfort were taken into account in this research study (Table 6).

When it comes to new methodologies, a multi-objective performance analysis (MOPA) model for early design of cost-optimal zero-energy lightweight construction was developed by Amer et al. [48]. Similarly to other MOO models, the MOPA workflow follows three consecutive steps such as modelling setup, BPS, and outcomes evaluation and selection. Alongside this, a VBA-based tool was implemented by Bayoumi and Fink [49] which enables design exploration of building façades for enhancing energy saving and energy generation. Such a tool was also capable of investigating the correlation between thermal and visual comforts.

Several journal articles described optimization procedures that were performed manually [50-55] (Figure 7). These studies mostly propose workflows to select the best among different pre-determined design alternatives through a comparative process. Design alternatives were not generated through GAs but implemented manually, thus reducing the results' reliability. Carriço de Lima Montenegro Duarte et al. [55] followed a similar approach when designing windows and shading devices in an educational building in Brazil with the aim of minimizing energy demand while improving visual and thermal comfort. Conversely, a multi-criteria methodology for optimization of residential buildings which is based on sensitive analysis was presented in Croitoru et al. [56]. This work described a parametric study regarding the impact on energy consumption with different factors and the weighing associated. 
Finally, Figure $8 \mathrm{~d}$ highlights that the energy performance was the most investigated objective function (34), followed by thermal comfort (19), solar accessibility (14), and life-cycle costs (13).

Table 6. Tabular review of journal articles about MOO workflows developed in an unspecified environment or in an environment different from Python, MATLAB, and Java.

\begin{tabular}{|c|c|c|c|c|c|c|c|c|c|c|c|c|c|c|c|c|c|c|c|c|}
\hline \multirow[b]{2}{*}{ 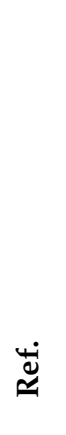 } & \multirow[b]{2}{*}{ હँّ } & \multicolumn{5}{|c|}{$\begin{array}{l}\text { Optimized } \\
\text { Parameters }\end{array}$} & \multirow[b]{2}{*}{ 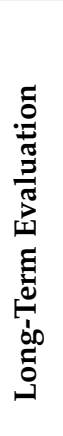 } & \multirow[b]{2}{*}{ 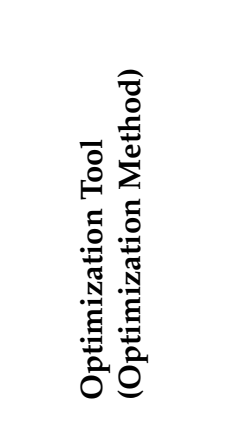 } & \multicolumn{12}{|c|}{ Parameters } \\
\hline & & U & U্త & 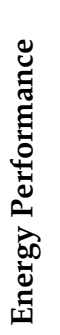 & 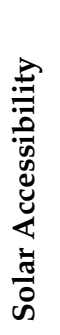 & 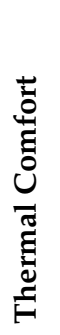 & & & & $\sum_{3}^{3}$ & $\begin{array}{l}20 \\
00 \\
00 \\
0 \\
0 \\
0 \\
0 \\
0 \\
0 \\
0 \\
0 \\
0 \\
3 \\
3\end{array}$ & 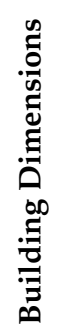 & 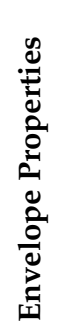 & 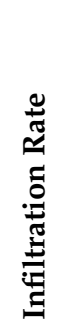 & 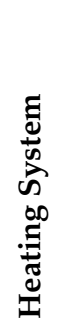 & 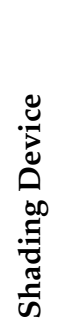 & 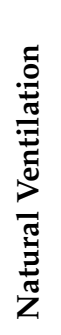 & 兵 & 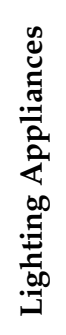 & 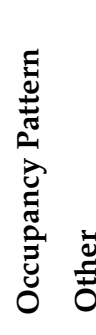 \\
\hline [49] & 2014 & & & $\mathbf{x}$ & $x$ & & $\mathbf{N}$ & MS Excel & & $\mathbf{x}$ & $\mathbf{x}$ & & & & & $\mathbf{x}$ & & & & \\
\hline [50] & 2015 & & & $x$ & $x$ & & $\mathbf{N}$ & Manually & & $\mathbf{x}$ & & & & & & & & & & \\
\hline [56] & 2016 & & & $x$ & & & $\mathbf{N}$ & Manually & $\mathbf{x}$ & & & & $\mathbf{x}$ & & & & & $x$ & & \\
\hline [47] & 2016 & & & $x$ & $\mathbf{x}$ & & $\mathbf{N}$ & $\begin{array}{c}\text { Visual } \\
\text { PROMETHEE }\end{array}$ & & & & & & & & $\mathbf{x}$ & & $\mathbf{x}$ & & \\
\hline [51] & 2016 & & & $\mathbf{x}$ & $x$ & & $\mathbf{N}$ & Manually & & $\mathbf{x}$ & $\mathbf{x}$ & & & & & & & & & \\
\hline [52] & 2016 & & & $\mathbf{x}$ & $x$ & & $\mathbf{N}$ & Manually & $\mathbf{x}$ & $\mathbf{x}$ & & $\mathbf{x}$ & & & & & & & & \\
\hline [45] & 2019 & & & $x$ & & & $\mathbf{N}$ & modeFRONTIER & & $\mathbf{x}$ & & & $\mathbf{x}$ & & $\mathbf{x}$ & & & & & \\
\hline [53] & 2020 & & & $x$ & & & $\mathbf{N}$ & Manually & & & & & & & & & $\mathbf{x}$ & & & \\
\hline [48] & 2020 & $x$ & & $x$ & & & $\mathbf{N}$ & MOPA & & & $\mathbf{x}$ & & $\mathbf{x}$ & & & & & $\mathbf{x}$ & & \\
\hline [54] & 2020 & & & $\mathbf{x}$ & $x$ & & $\mathbf{N}$ & Manually & $\mathbf{x}$ & & & $\mathbf{x}$ & & & & & & & & \\
\hline [46] & 2020 & & & $x$ & & & $\mathbf{N}$ & modeFRONTIER & & $\mathbf{x}$ & $\mathbf{x}$ & & $\mathbf{x}$ & $\mathbf{x}$ & $\mathbf{x}$ & & & $\mathbf{x}$ & & \\
\hline [55] & 2021 & & & $\mathbf{x}$ & $\mathbf{x}$ & & $\mathbf{N}$ & Manually & & $\mathbf{x}$ & $\mathbf{x}$ & & & & & $\mathbf{x}$ & $\mathbf{x}$ & & & \\
\hline
\end{tabular}

\subsection{Knowledge Gaps and Future Trends}

The review process of journal articles concerning MOO models for integrated building design permitted us to identify the knowledge gaps which are described in the following paragraphs. Firstly, almost the totality of the journal articles avoided taking into account climate change effects in their MOO models. Statistical weather files, which are based on mean values of climate variables calculated over the past 15 years, or monitored data were used by leading to biased optimization outcomes. Such a bias was more evident when the whole building life cycle was considered. In fact, the building lifetime is generally considered to be as high as 60 years, and climate parameters such as the near-surface air temperature and the radiative forcing are expected to change within this time interval. Therefore, the effectiveness of optimized strategies and technologies for cooling might be reduced throughout the building's lifetime. Several research studies such as the ones carried out by Allouhi [57] and Zou et al. [58] started filling such a knowledge gap by proposing temporal dynamic optimization procedures which integrate BPO with mediumand long-term impact assessment of climate change effects.

Secondly, the reviewed workflows were found to perform optimization at a single scale such as neighbourhood, building, and room scale without linking them. A multi-scale approach is necessary to consider inter-building effects and mutual influences between the indoor and the outdoor environment. For example, the application of a highly reflective coating on a building façade for passively cooling the indoor environment may also lead 
to an increase in the solar radiation impinging on near urban surfaces (i.e., buildings envelopes, street surface, pedestrian areas) by worsening the thermal stress of pedestrians. Therefore, it is necessary to establish MOO models operating at multiple spatial scales which enable solving objective functions concerning different environments (i.e., the room and the whole building, the building and the street environment, the building and the neighbourhood) at the same time.

Thirdly, coupling different building typologies such as office, commercial, and residential can be an effective strategy to further improve building energy management and it might represent a relevant future trend in the integrated building design research field [59]. Several journal articles have already investigated how occupancy-related variables such as occupancy pattern, indoor temperature set-point, and lighting conditions can impact energy, users' comfort, emissions, and costs [16,30,37,60,61]. Following this, future works should consider combining different occupancy typologies to enhance buildings' energy, economic, and environmental sustainability.

Finally, around $15 \%$ of the reviewed journal articles performed LCA analyses, but they mostly focused on the operational stage by avoiding investigating emissions embodied in construction materials [62,63]. The building energy consumption is generally converted into carbon emissions through the energy mix factor. It is worth highlighting that such a knowledge gap has been partially filled by Azari et al. [64] and by Lobaccaro et al. [21], but further investigations are needed to develop multi-criteria workflows including embodied emissions assessment.

Following this, the future trends in designing a responsive built environment will concern the implementation of a new generation of MOO models capable to operate at multiple spatial and temporal scales with increased attention towards the minimization of emissions embodied in construction materials. Such a holistic approach to building and neighbourhood optimization will necessarily take advantage of benefits related to the combination of different building typologies in order to further enhance the building's energy efficiency. All these aspects can now be taken into account thanks to the recent implementation of metamodels which enable lower computational time for BPS.

\section{Conclusions}

A synthetic review of MOO models is carried out in order to design responsive buildings and neighbourhoods. The review focused on the utilized software during both simulation and optimization stages, as well as on the identified objective functions and design variables. Results highlighted that MOO models are widely exploited for defining a trade-off between building energy efficiency (i.e., minimization of energy demand for heating and cooling, maximization of energy production from RES) and thermal and visual comfort. In addition to that, some research studies demonstrated that such GAs are suitable for minimizing construction costs as well as operational emissions. The reviewed MOO models can only perform optimization at a single scale, mainly handling variables related to characteristics of a building or a test room. Among the optimized design variables, the commonest were the ones describing the building's envelope, the glazed surfaces, and the shading devices. The possibility of exploring different shape solutions for the building case study was only implemented in a few works.

Automation for integrated building design has been improving significantly between 2014 and 2021 due to the implementation of numerous MOO models that rapidly substituted the previous single-objective optimization algorithms. Nonetheless, there are still some aspects that need to be further enhanced to fully enable the potential of optimization tools in the design of responsive building solutions, in particular, the capability of optimizing design variables and of solving objective functions at multiple scales by also taking into account climate change effects. This is expected to be the future trend about such a research topic together with the development of $\mathrm{MOO}$ models that can investigate sector coupling solutions to achieve higher energy efficiency levels. 
When it comes to the limitations of the work, it is worth underlining that this review study focused more on the methodology than on the results of the reviewed publications. Therefore, a partial overview of the potentialities of MOO models is provided by neglecting their effectiveness in designing responsive buildings. Following this, future developments of this study must necessarily consider this aspect when reviewing MOO models.

Author Contributions: Conceptualization, M.M.; methodology, A.N. and M.M.; software, M.M.; formal analysis, M.M.; investigation, A.N and M.M.; resources, A.N.; data curation, M.M.; writing-original draft preparation, M.M.; writing—review and editing, A.N.; visualization, M.M.; supervision, A.N. All authors have read and agreed to the published version of the manuscript.

Funding: This research received no external funding.

Institutional Review Board Statement: Not applicable.

Informed Consent Statement: Not applicable.

Data Availability Statement: Not applicable.

Conflicts of Interest: The authors declare no conflict of interest.

\section{Nomenclature}

GHG Greenhouse gases

ZEB Zero-energy building

BPS Building performance simulation

GA Genetic algorithm

MOO Multi-objective optimization

BPO Building performance optimization

MOPSO Multi-objective particle-swarm optimization

SPEA2 Strength Pareto evolutionary algorithm

NSGA-II Non-sorting genetic algorithm

ANN Artificial neural network

WoS Web of Science

LCC Life-cycle cost

VBA Visual Basic for Applications

LCA Life-cycle assessment

WWR Window-to-wall ratio

RES Renewable energy source

MOBO Multi-objective building optimization

MOPA Multi-objective performance analysis 


\section{Appendix A}

Table A1. Tabular review of the selected journal articles.

\begin{tabular}{|c|c|c|c|c|c|c|c|c|c|c|c|c|c|c|c|c|c|c|c|c|c|c|c|c|}
\hline \multirow[b]{2}{*}{$\stackrel{\breve{\Xi}}{\dddot{\Xi}}$} & \multirow[b]{2}{*}{ હ્ર } & \multirow[b]{2}{*}{ 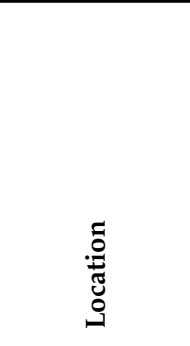 } & \multirow[b]{2}{*}{$\begin{array}{l}\overrightarrow{\vec{\theta}} \\
\vec{\Xi} \\
\tilde{D} \\
\tilde{D} \\
\tilde{D} \\
\tilde{U}\end{array}$} & \multicolumn{5}{|c|}{ Optimized Parameters } & \multirow[b]{2}{*}{ 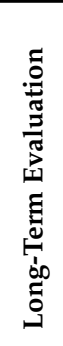 } & \multirow[b]{2}{*}{ 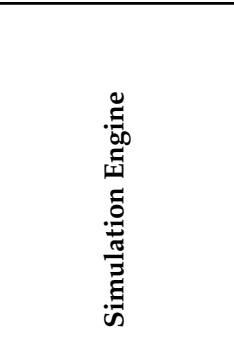 } & \multirow[b]{2}{*}{ 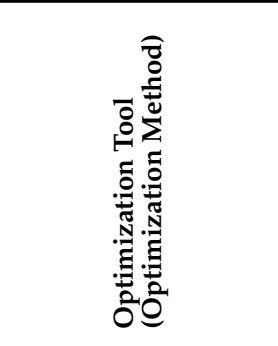 } & \multicolumn{13}{|c|}{ Parameters } \\
\hline & & & & U] & త্త & 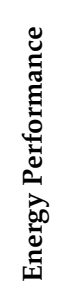 & 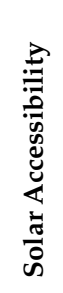 & 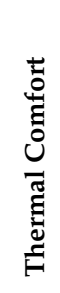 & & & & 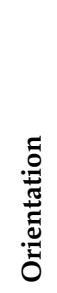 & $\frac{1}{3}$ & 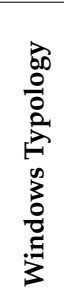 & 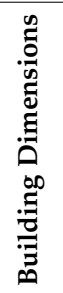 & 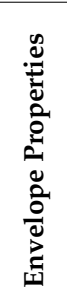 & 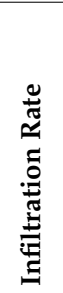 & 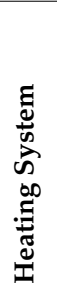 & 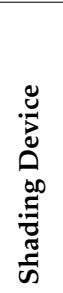 & 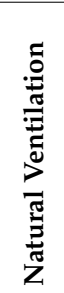 & 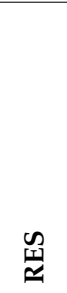 & 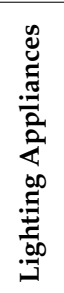 & 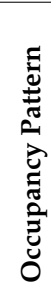 & ذँ \\
\hline [49] & 2014 & Saudi Arabia & office building & & & $x$ & $x$ & & $\mathbf{N}$ & MS Excel & MS Excel & & $x$ & $x$ & & & & & $x$ & & & & & \\
\hline [63] & 2014 & Germany & office building & $x$ & $x$ & $x$ & & & $\mathbf{N}$ & MS Excel & n.d. & & & $x$ & & $x$ & $\mathbf{x}$ & $x$ & & & & & & \\
\hline [65] & 2014 & Netherlands & office building & & & $x$ & $\mathrm{x}$ & & $\mathbf{N}$ & $\begin{array}{l}\text { TRNSYS, } \\
\text { Radiance }\end{array}$ & n.d. & & $x$ & $x$ & & $\mathbf{x}$ & & & & & & & & \\
\hline [27] & 2015 & UK & residential building & & & $x$ & $x$ & & $\mathbf{N}$ & Autodesk GBS & Optimo & & $x$ & $x$ & & & & & & & & & & \\
\hline [50] & 2015 & Japan & office building & & & $x$ & $\mathbf{x}$ & & $\mathbf{N}$ & $\begin{array}{c}\text { Radiance, } \\
\text { EnergyPlus }\end{array}$ & Manually & & $x$ & & & & & & & & & & & \\
\hline [42] & 2015 & USA & educational building & & & $\mathbf{x}$ & $x$ & & $\mathbf{N}$ & $\begin{array}{c}\text { Radiance, } \\
\text { EnergyPlus }\end{array}$ & GenOpt & & $x$ & $x$ & & & & & $\mathbf{x}$ & & & & & $\mathbf{x}$ \\
\hline [62] & 2015 & miscellaneous & office building & & & $x$ & & & $\mathbf{N}$ & EnergyPlus & Python & & $x$ & $x$ & & $x$ & & & & & & & & \\
\hline [23] & 2015 & Denmark & office building & $x$ & & $x$ & $x$ & & $\mathbf{N}$ & Radiance, Be10 & Octopus & & & & $\mathbf{x}$ & & & & & & & & & \\
\hline [37] & 2015 & USA & residential building & $x$ & $x$ & & $x$ & & $\mathbf{N}$ & EnergyPlus & $M A T L A B$ & & $x$ & $x$ & & $x$ & & $x$ & & & & $x$ & $x$ & \\
\hline [66] & 2015 & miscellaneous & commercial building & $x$ & & $x$ & & & $\mathbf{N}$ & EnergyPlus & n.d. & $x$ & $x$ & $x$ & & $x$ & & $x$ & & & & & $x$ & \\
\hline [67] & 2015 & Hong Kong & office building & $x$ & $x$ & & & & $\mathbf{N}$ & TRNSYS & $M A T L A B$ & & & & & & & & & & $x$ & & & \\
\hline [68] & 2015 & China & residential building & & & $x$ & & & $\mathbf{N}$ & EnergyPlus & MATLAB & $x$ & $x$ & $x$ & $x$ & $x$ & & & & & & & & \\
\hline [33] & 2015 & Australia & residential building & $x$ & $x$ & & & & $\mathbf{N}$ & SimaPro & LINDO & & & $x$ & & $x$ & & & & & & & & \\
\hline [56] & 2016 & Romania & residential building & & & $x$ & & & $\mathbf{N}$ & DesignBuilder & Manually & $x$ & & & & $x$ & & & & & $x$ & & & \\
\hline [47] & 2016 & Greece & office building & & & $x$ & $x$ & & $\mathbf{N}$ & n.d. & Visual PROMETHEE & & & & & & & & $\mathbf{x}$ & & $x$ & & & \\
\hline [51] & 2016 & Serbia & office building & & & $x$ & $x$ & & $\mathbf{N}$ & $\begin{array}{c}\text { Radiance, } \\
\text { EnergyPlus }\end{array}$ & Manually & & $\mathbf{x}$ & $x$ & & & & & & & & & & \\
\hline [69] & 2016 & Norway & residential building & & $x$ & & $x$ & & $\mathbf{N}$ & Ladybug, Honeybee & Octopus & & & & $x$ & & & & & & & & & \\
\hline [70] & 2016 & Argentina & residential building & & & $x$ & & & $\mathbf{N}$ & EnergyPlus & Python & $x$ & $x$ & $x$ & & $x$ & $x$ & & $x$ & & & & & \\
\hline$[6]$ & 2016 & miscellaneous & residential building & & & $x$ & & & $\mathbf{N}$ & DesignBuilder & n.d. & & $\mathbf{x}$ & $x$ & & $x$ & & & $x$ & & & & & \\
\hline
\end{tabular}


Table A1. Cont.

\begin{tabular}{|c|c|c|c|c|c|c|c|c|c|c|c|c|c|c|c|c|c|c|c|c|c|c|c|}
\hline \multirow[b]{2}{*}{ 苞 } & \multirow[b]{2}{*}{ હँّ } & \multirow[b]{2}{*}{ 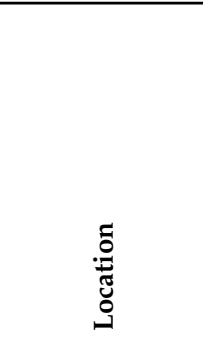 } & \multirow[b]{2}{*}{$\begin{array}{l}\overrightarrow{\vec{Z}} \\
\vec{E} \\
\tilde{\omega} \\
\tilde{D} \\
\tilde{J}\end{array}$} & \multicolumn{5}{|c|}{ Optimized Parameters } & \multirow[b]{2}{*}{ 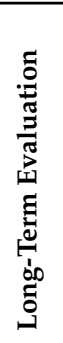 } & \multirow[b]{2}{*}{ 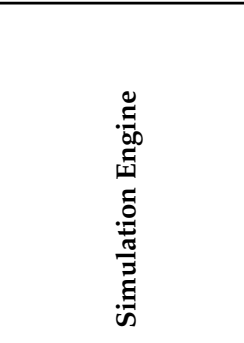 } & \multirow[b]{2}{*}{ 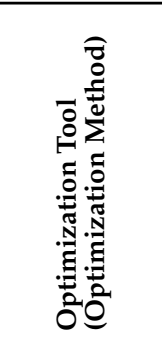 } & \multicolumn{12}{|c|}{ Parameters } \\
\hline & & & & $\underset{U}{U}$ & త্త & 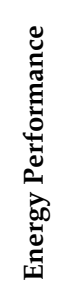 & 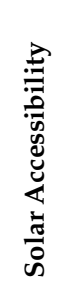 & 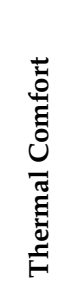 & & & & 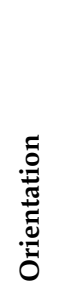 & $\sum_{3}^{\frac{\alpha}{3}}$ & 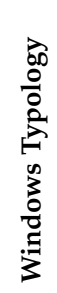 & 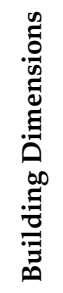 & 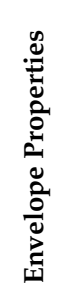 & 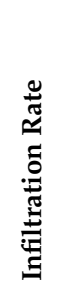 & 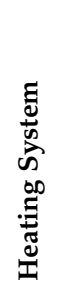 & 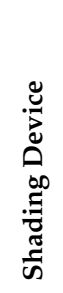 & 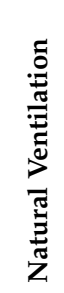 & $\begin{array}{l}\infty \\
\simeq \\
\simeq 1\end{array}$ & 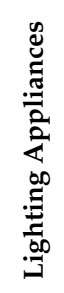 & 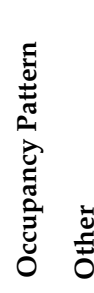 \\
\hline [24] & 2016 & Spain & residential building & $x$ & $x$ & $x$ & & & $\mathbf{N}$ & EnergyPlus & jEPlus & & & & & $x$ & & & & & & & \\
\hline [71] & 2016 & Hong Kong & residential building & & & & $x$ & & $\mathbf{N}$ & EnergyPlus & jEPlus & $x$ & $x$ & $x$ & & $x$ & $x$ & & & & & & \\
\hline [61] & 2016 & USA & other & $x$ & & & & & $\mathbf{N}$ & $\begin{array}{c}\text { DesignBuilder, } \\
\text { RSMeans, MySQLL }\end{array}$ & n.d. & & & $x$ & & $\mathbf{x}$ & & $\mathrm{x}$ & & & & $\mathbf{x}$ & $\mathbf{x}$ \\
\hline [72] & 2016 & Iran & office building & & & $x$ & $x$ & & $\mathbf{N}$ & EnergyPlus & MATLAB & $x$ & $x$ & & & & & & $x$ & & & & \\
\hline [64] & 2016 & USA & office building & & $x$ & $\mathbf{x}$ & & & $\mathbf{N}$ & eQuest, AthenaIE & n.d. & & $x$ & $x$ & & $\mathrm{x}$ & & & & & & & \\
\hline [73] & 2016 & China & other & & & & $x$ & & $\mathbf{N}$ & Ladybug & Octopus & & & & $\mathbf{x}$ & & & & & & & & \\
\hline [74] & 2016 & Iran & test room & & & $x$ & & & $\mathbf{N}$ & EnergyPlus & jEPlus & $\mathbf{x}$ & $x$ & $x$ & & $x$ & & & $x$ & & & & \\
\hline [75] & 2016 & Portugal & residential building & & & $x$ & & & $\mathbf{N}$ & EnergyPlus & n.d. & $\mathbf{x}$ & & $x$ & & $x$ & & & & $x$ & & & \\
\hline [30] & 2016 & Hong Kong & office building & $x$ & & $x$ & & & $\mathbf{N}$ & EnergyPlus & MATLAB & & & $x$ & & & & $\mathbf{x}$ & & & & & \\
\hline [76] & 2016 & miscellaneous & office building & & & $x$ & $x$ & & $\mathbf{N}$ & $\begin{array}{c}\text { Radiance, } \\
\text { EnergyPlus }\end{array}$ & Octopus & $\mathbf{x}$ & $\mathbf{x}$ & $\mathbf{x}$ & $\mathbf{x}$ & $\mathrm{x}$ & & & & & & & \\
\hline [20] & 2017 & Italy & educational building & & & $x$ & & & $\mathbf{N}$ & Ladybug, Honeybee & Octopus & & & & & & & & & & & & $x$ \\
\hline [31] & 2017 & France & residential building & $x$ & & $x$ & & & $\mathbf{N}$ & TRNSYS & MATLAB & & & $x$ & & $x$ & & $x$ & & & & & \\
\hline [77] & 2017 & Argentina & residential building & & & $x$ & & & $\mathbf{N}$ & EnergyPlus & Python & $x$ & $x$ & $x$ & & $x$ & $x$ & & $x$ & $x$ & & & \\
\hline [17] & 2017 & Spain & residential building & $x$ & & $x$ & & & $\mathbf{N}$ & DIVA & Galapagos & & & $x$ & & $x$ & & & $x$ & & & & \\
\hline [78] & 2017 & miscellaneous & residential building & & & $x$ & $x$ & & $\mathbf{N}$ & EnergyPlus, $R$ & jEPlus & $x$ & $x$ & $x$ & & $x$ & $x$ & & & & & & \\
\hline [38] & 2018 & Italy & office building & $x$ & $x$ & $x$ & & & $\mathbf{N}$ & EnergyPlus & MATLAB & & & $\mathbf{x}$ & & $x$ & & & & & $x$ & & \\
\hline [79] & 2018 & Italy & other & $x$ & $x$ & $x$ & $x$ & & $\mathbf{N}$ & n.d. & n.d. & & & & & & & & & & $x$ & & \\
\hline [25] & 2018 & miscellaneous & residential building & $x$ & & $x$ & & & $\mathbf{N}$ & TRNSYS & MOBO tool & & $x$ & $x$ & & $x$ & & & & & & & \\
\hline [21] & 2018 & Norway & residential building & & $x$ & & $x$ & & $\mathbf{N}$ & Ladybug, Honeybee & Octopus & $x$ & $x$ & & $\mathbf{x}$ & $x$ & & & & & & & \\
\hline [80] & 2018 & China & residential building & & & $x$ & & & $\mathbf{N}$ & EnergyPlus & MATLAB & $x$ & $x$ & $x$ & & $x$ & $x$ & & $x$ & $x$ & & & \\
\hline [44] & 2018 & Italy & educational building & & & $x$ & $x$ & & $\mathbf{N}$ & TRNSYS & GenOpt & & $x$ & $x$ & & $x$ & & & $x$ & & & & \\
\hline [81] & 2018 & Poland & residential building & $\mathrm{x}$ & & & & & $\mathbf{N}$ & EnergyPlus & MATLAB & $\mathbf{x}$ & $x$ & $x$ & & $x$ & $x$ & & & & & & \\
\hline
\end{tabular}


Table A1. Cont.

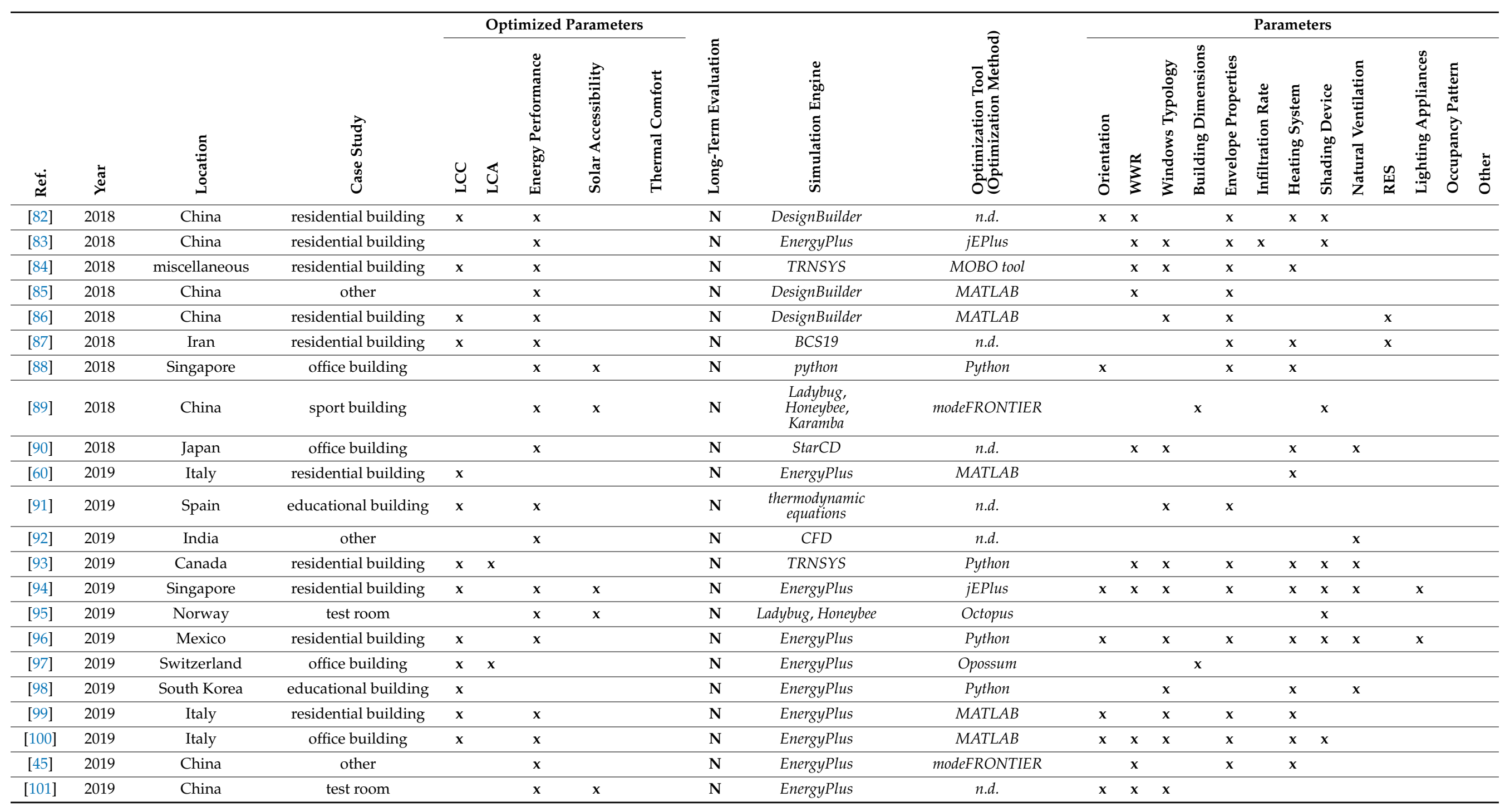


Table A1. Cont.

\begin{tabular}{|c|c|c|c|c|c|c|c|c|c|c|c|c|c|c|c|c|c|c|c|c|c|c|c|c|}
\hline \multirow[b]{2}{*}{$\stackrel{\overleftrightarrow{\Xi}}{\cong}$} & \multirow[b]{2}{*}{ ฮ્ર } & \multirow[b]{2}{*}{ 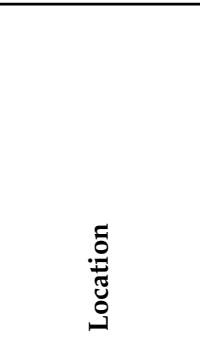 } & \multirow[b]{2}{*}{ 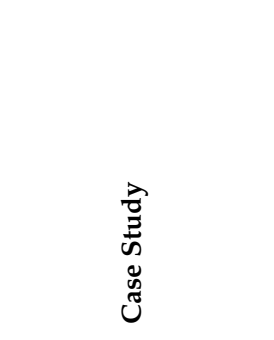 } & \multicolumn{5}{|c|}{ Optimized Parameters } & \multirow[b]{2}{*}{ 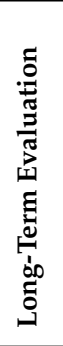 } & \multirow[b]{2}{*}{ 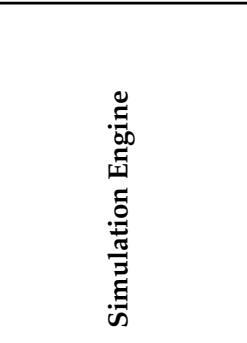 } & \multirow[b]{2}{*}{ 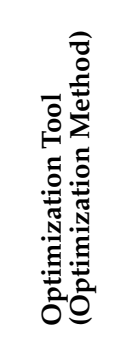 } & \multicolumn{13}{|c|}{ Parameters } \\
\hline & & & & U & త্త & 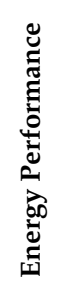 & 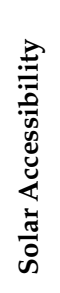 & 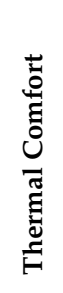 & & & & 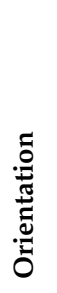 & 3 & 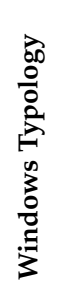 & 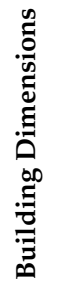 & 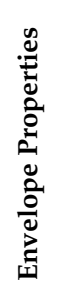 & 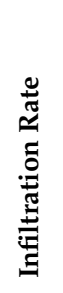 & 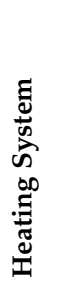 & 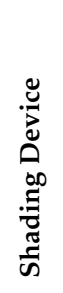 & 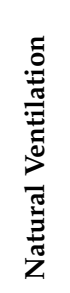 & $\underset{\simeq}{\simeq}$ & 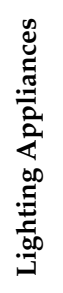 & 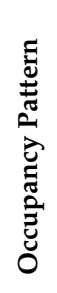 & ث্ّ \\
\hline [102] & 2019 & Sweden & residential building & & & $x$ & & & $\mathbf{N}$ & Honeybee & Octopus & $x$ & $x$ & & $x$ & $x$ & & & & & & & & \\
\hline [103] & 2020 & China & other & & & $x$ & & & $\mathbf{N}$ & n.d. & n.d. & & & & & & & & & & & & $x$ & \\
\hline [53] & 2020 & Turkey & residential building & & & $\mathrm{x}$ & & & $\mathbf{N}$ & $\begin{array}{l}\text { Autodesk CFD, } \\
\text { eQUEST }\end{array}$ & Manually & & & & & & & & & $\mathrm{x}$ & & & & \\
\hline [104] & 2020 & n.d. & other & & & $x$ & $x$ & & $\mathbf{N}$ & Data driven & n.d. & & & & & & & $x$ & & $x$ & & $x$ & & \\
\hline [105] & 2020 & miscellaneous & residential building & & $x$ & & $x$ & & $\mathbf{N}$ & Ladybug, Honeybee & Octopus & $x$ & $x$ & & $x$ & $x$ & & & & & & & & \\
\hline$[48]$ & 2020 & Belgium & other & $x$ & & $x$ & & & $\mathbf{N}$ & Ladybug, Honeybee & MOPA & & & $x$ & & $x$ & & & & & $x$ & & & \\
\hline [36] & 2020 & Italy & neighborhood & $x$ & & $x$ & $x$ & & $\mathbf{N}$ & EnergyPlus & MATLAB & & & & & $x$ & & $x$ & & & $x$ & & & \\
\hline [16] & 2020 & Iran & educational building & & & $x$ & & & $\mathbf{N}$ & Ladybug, Honeybee & Galapagos & & & & & $x$ & $x$ & & & & & $x$ & $x$ & \\
\hline [107] & 2020 & Denmark & office building & & & $x$ & & & $\mathbf{N}$ & EnergyPlus & MOBO & & & & & & & & & $x$ & & & & \\
\hline$[34]$ & 2020 & China & residential building & & & $x$ & $x$ & & $\mathbf{N}$ & EnergyPlus & MATLAB & $x$ & $x$ & $x$ & & $x$ & & $x$ & & & & $x$ & & \\
\hline [39] & 2020 & Japan & residential building & $\mathbf{x}$ & $x$ & $x$ & & & $\mathbf{N}$ & Ladybug, Honeybee & MATLAB & & & $x$ & & $x$ & & & & & $x$ & & & \\
\hline [15] & 2020 & USA & office building & & & $x$ & $x$ & & $\mathbf{N}$ & Ladybug, Honeybee & Octopus & & & & & & & & $x$ & & & & & \\
\hline [108] & 2020 & Oman & residential building & $x$ & & $x$ & & & $\mathbf{N}$ & EnergyPlus & MATLAB & & $x$ & $x$ & & $x$ & & & $x$ & & & & & \\
\hline [109] & 2020 & South Korea & office building & & & $x$ & & & $\mathbf{N}$ & EnergyPlus & MATLAB & & & & & & & $x$ & & & & & & \\
\hline$[54]$ & 2020 & Sweden & neighborhood & & & $x$ & $x$ & & $\mathbf{N}$ & Honeybee & Manually & $x$ & & & $x$ & & & & & & & & & \\
\hline [29] & 2020 & Australia & residential building & & & $x$ & $x$ & & $\mathbf{N}$ & n.d. & Optimo & & $x$ & $x$ & & & & & & & & & & \\
\hline [110] & 2020 & Portugal & residential building & & & $x$ & & & $\mathbf{N}$ & EnergyPlus & n.d. & & $x$ & & & $x$ & $x$ & & & & & & & $x$ \\
\hline [111] & 2020 & Mauritius & residential building & $x$ & $x$ & & & & $\mathbf{N}$ & EnergyPlus & jEPlus & $x$ & & $x$ & & $x$ & & & & & & & & \\
\hline [112] & 2020 & Iran & residential building & $\mathbf{x}$ & & $x$ & & & $\mathbf{N}$ & EnergyPlus & n.d. & & & & & $x$ & $x$ & & & & & $x$ & & \\
\hline$[28]$ & 2020 & Australia & residential building & & $x$ & $x$ & & & $\mathbf{N}$ & EnergyPlus & Optimo & & & & & $x$ & & & & & & & & \\
\hline [41] & 2020 & Portugal & residential building & $x$ & & $\mathrm{x}$ & & & $\mathbf{N}$ & $\begin{array}{l}\text { thermodynamic } \\
\text { equations }\end{array}$ & MATLAB & & & & & & & $\mathbf{x}$ & & & $x$ & & & \\
\hline
\end{tabular}


Table A1. Cont.

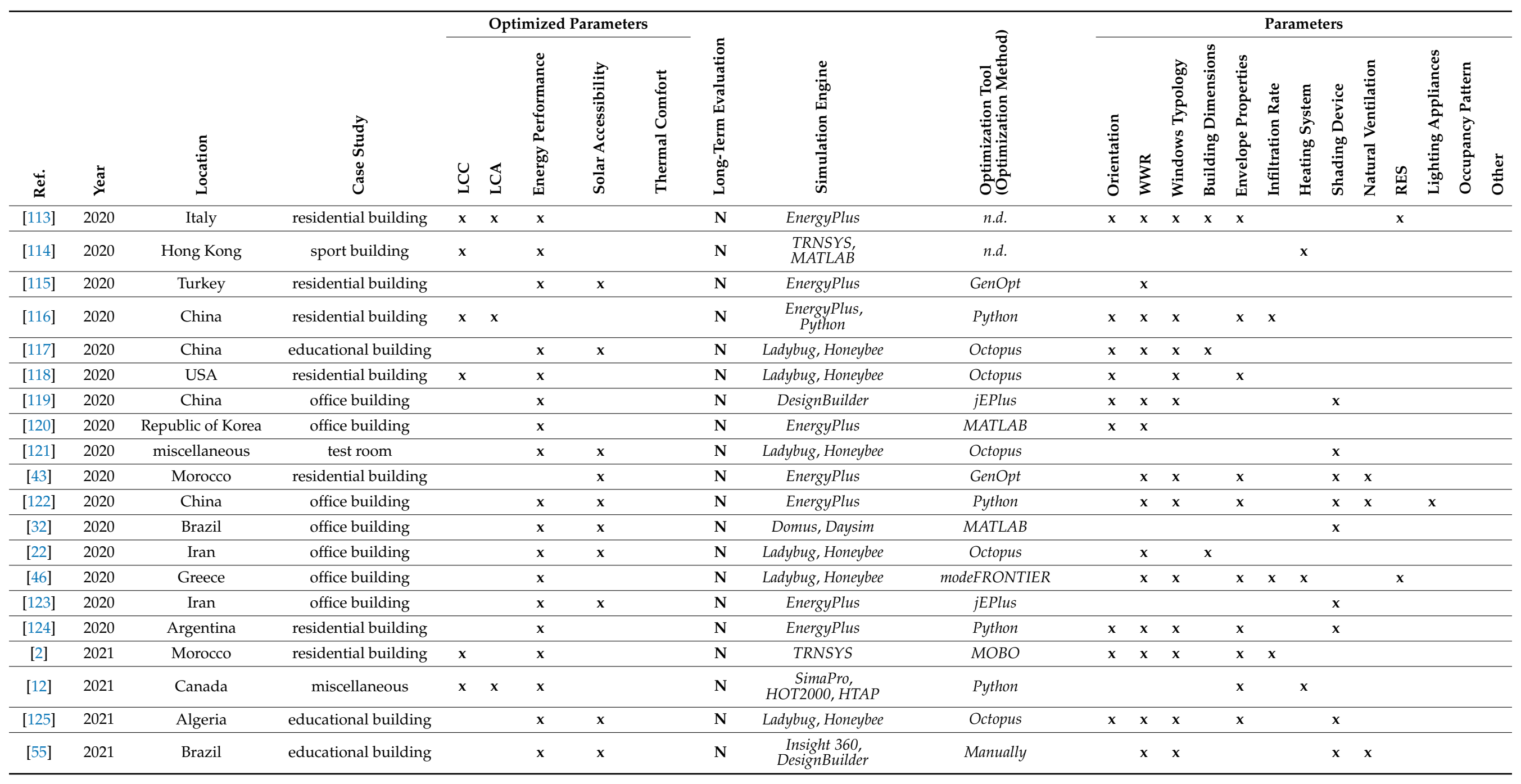


Table A1. Cont.

\begin{tabular}{|c|c|c|c|c|c|c|c|c|c|c|c|c|c|c|c|c|c|c|c|c|c|c|c|c|}
\hline \multirow[b]{2}{*}{ 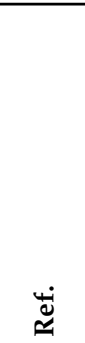 } & \multirow[b]{2}{*}{ ప্̋ } & \multirow[b]{2}{*}{.气 } & \multirow[b]{2}{*}{ 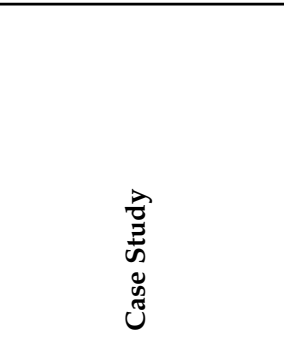 } & \multicolumn{5}{|c|}{ Optimized Parameters } & \multirow[b]{2}{*}{ 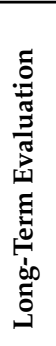 } & \multirow[b]{2}{*}{ 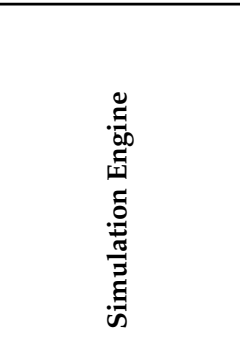 } & \multirow[b]{2}{*}{ 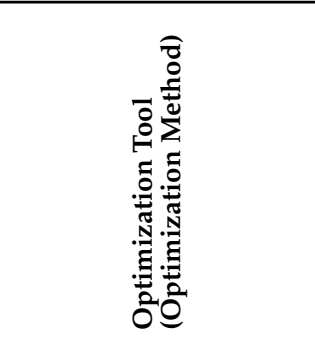 } & \multicolumn{13}{|c|}{ Parameters } \\
\hline & & & & U & త্త & 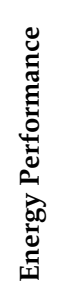 & 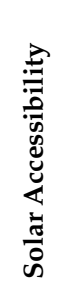 & 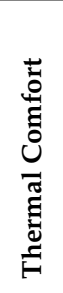 & & & & 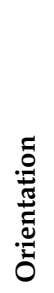 & $\frac{\pi}{3}$ & 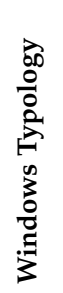 & 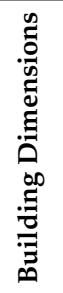 & 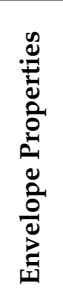 & 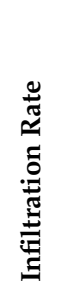 & 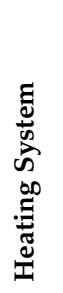 & 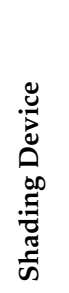 & 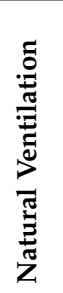 & 里 & 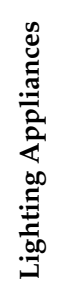 & 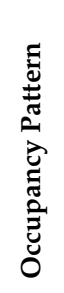 & ثี \\
\hline [126] & 2021 & China & office building & & & $x$ & $x$ & & $\mathbf{N}$ & $\begin{array}{c} \\
\text { Dynamo, Radiance, } \\
\text { Daysim, Green } \\
\text { Building Studio, } \\
\text { MATLAB } \\
\text { (Self-Organizing } \\
\text { Mapping) }\end{array}$ & n.d. & & $x$ & & $\mathbf{x}$ & & & & & & & & & \\
\hline [127] & 2021 & UK & office building & $x$ & $x$ & $x$ & & & $\mathbf{N}$ & Data driven & n.d. & & & & & $x$ & & $x$ & & & $x$ & & & \\
\hline [128] & 2021 & China & test room & & & $x$ & $x$ & & $\mathbf{N}$ & Ladybug, Honeybee & Octopus & & & $x$ & & & & & & & & & & \\
\hline$[58]$ & 2021 & China & educational building & & & $x$ & $x$ & & $Y$ & Ladybug, Honeybee & Python & $x$ & $x$ & $x$ & $x$ & $x$ & & & $x$ & & & & & \\
\hline [129] & 2021 & China & residential building & $x$ & & $x$ & & & $\mathbf{N}$ & EnergyPlus & MATLAB & & & $x$ & & $x$ & & & & & $x$ & & & \\
\hline [130] & 2021 & Malaysia & test room & & & $x$ & $x$ & & $\mathbf{N}$ & Ladybug, Honeybee & Octopus & & & & & & & & & & & & & $x$ \\
\hline [132] & 2021 & China & educational building & & & $x$ & & & $\mathbf{N}$ & DesignBuilder & Design-Expert & & $x$ & $x$ & & $x$ & & & & & & & & \\
\hline [35] & 2021 & Iran & office building & & & $x$ & & & $\mathbf{N}$ & EnergyPlus & MATLAB & & & & & $x$ & $x$ & $x$ & & $x$ & & & & \\
\hline$[26]$ & 2021 & miscellaneous & residential building & & & $x$ & & & $\mathrm{Y}$ & EnergyPlus & jEPlus & & $x$ & $x$ & $x$ & $x$ & & & & $x$ & & & & \\
\hline [133] & 2021 & Italy & neighbourhood & $x$ & & & $x$ & & $\mathbf{N}$ & EnergyPlus & MATLAB & & & $x$ & & $x$ & & $x$ & & & $x$ & & & \\
\hline [134] & 2021 & Turkey & residential building & $x$ & & $x$ & & & $\mathbf{N}$ & EnergyPlus & MATLAB & $x$ & $x$ & $x$ & & $x$ & & & & & & & & \\
\hline [135] & 2021 & miscellaneous & educational building & & & $\mathbf{x}$ & & & $\mathbf{N}$ & $\begin{array}{c}\text { Ladybug, } \\
\text { ClimateStudio for } \\
\text { Rhino }\end{array}$ & Design Space Exploration & & & & & & & $\mathbf{x}$ & & & & & $x$ & \\
\hline [18] & 2021 & Iran & office building & & & $x$ & $\mathbf{x}$ & & $\mathbf{N}$ & $\begin{array}{c}\text { Ladybug, } \\
\text { Honeybee, } \\
\text { EnergyPlus, } \\
\text { OpenStudio, } \\
\text { Daysim }\end{array}$ & Colibrì, Octopus & & $\mathbf{x}$ & $\mathbf{x}$ & & & & & & & & & & \\
\hline [136] & 2021 & USA & office building & & & $x$ & $x$ & & $\mathbf{N}$ & Ladybug, Honeybee & n.d. & & & & & & & & $x$ & & & & & \\
\hline [137] & 2021 & China & residential building & & & & $x$ & & $\mathbf{N}$ & QuVue, Eddy3d & $M A T L A B$ & & & & $x$ & & & & & & & & & \\
\hline [138] & 2021 & Serbia & residential building & & & $x$ & & & $\mathbf{N}$ & DesignBuilder & n.d. & & $x$ & $x$ & & $x$ & & & $x$ & & & & & \\
\hline [139] & 2021 & Shanghai & residential building & $x$ & & & & & $\mathbf{N}$ & DesignBuilder & n.d. & & $x$ & $x$ & & $x$ & & $x$ & $x$ & & $\mathrm{x}$ & & & \\
\hline
\end{tabular}


Table A1. Cont.

\begin{tabular}{|c|c|c|c|c|c|c|c|c|c|c|c|c|c|c|c|c|c|c|c|c|c|c|c|c|}
\hline \multirow[b]{2}{*}{$\ddot{\mathscr{\Xi}}$} & \multirow[b]{2}{*}{ むँ } & \multirow[b]{2}{*}{ 园 } & \multirow[b]{2}{*}{ 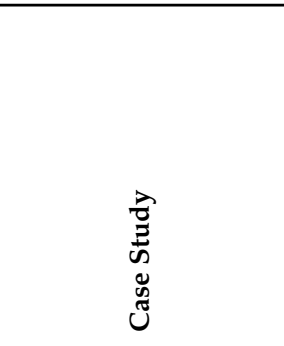 } & \multicolumn{5}{|c|}{ Optimized Parameters } & \multirow[b]{2}{*}{ 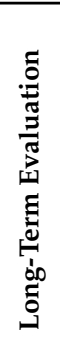 } & \multirow[b]{2}{*}{ 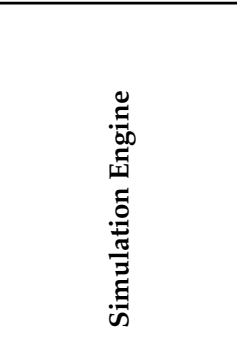 } & \multirow[b]{2}{*}{ 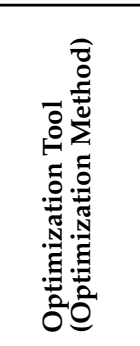 } & \multicolumn{13}{|c|}{ Parameters } \\
\hline & & & & U & త্త & 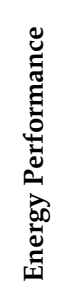 & 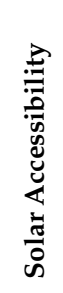 & 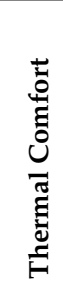 & & & & 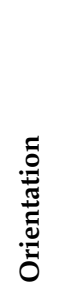 & $\frac{2}{3}$ & 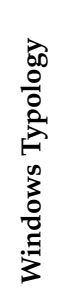 & 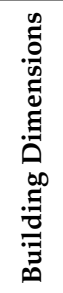 & 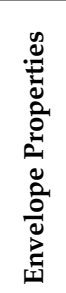 & 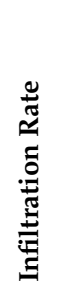 & 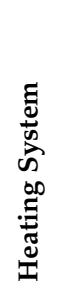 & 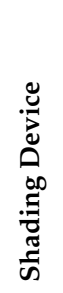 & 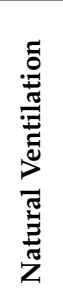 & 乐 & 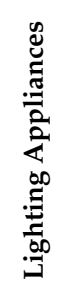 & 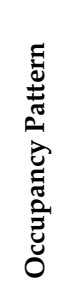 & $\stackrel{\Xi}{0}$ \\
\hline [19] & 2021 & China & educational building & $x$ & & $x$ & & & $\mathbf{N}$ & Ladybug, Honeybee & Octopus & & & $x$ & & $x$ & & & & & & & & \\
\hline [140] & 2021 & Australia & test room & & & & $x$ & & $\mathbf{N}$ & CFStrace & n.d. & & & $x$ & & & & & & & & & & \\
\hline [141] & 2021 & Brazil & residential building & & & $x$ & & & $\mathbf{N}$ & EnergyPlus & MATLAB & & & $x$ & & $x$ & $x$ & & & & & & & \\
\hline [142] & 2021 & Italy & educational building & $x$ & & $x$ & $x$ & & $\mathbf{N}$ & Ladybug, Honeybee & MATLAB & $\mathbf{x}$ & $x$ & $\mathbf{x}$ & & $x$ & & & $x$ & & & & & \\
\hline [143] & 2021 & China & educational building & & & $x$ & & & $\mathbf{N}$ & DesignBuilder & MATLAB & & $x$ & $x$ & & $\mathbf{x}$ & & & & & & & & \\
\hline$[144]$ & 2021 & Iran & residential building & & $\mathbf{x}$ & $\mathbf{x}$ & & & $\mathbf{N}$ & $\begin{array}{c}\text { Ladybug, } \\
\text { Honeybee, Revit }\end{array}$ & Octopus & & & $\mathbf{x}$ & & $\mathbf{x}$ & & & & & $\mathbf{x}$ & & & \\
\hline [145] & 2021 & Australia & residential building & $x$ & & & $x$ & & $\mathbf{N}$ & TRNSYS & jEPlus & & $x$ & $x$ & & $\mathrm{x}$ & & & $\mathbf{x}$ & & & & & \\
\hline [146] & 2021 & Australia & miscellaneous & $x$ & & $x$ & $x$ & & $\mathbf{N}$ & Revit, Insight & $A M P L$ & & $x$ & $x$ & & $x$ & & & & & & $x$ & & \\
\hline [148] & 2021 & Sweden & residential building & & $x$ & $x$ & & & $\mathbf{N}$ & EnergyPlus & Python & & & $x$ & & $x$ & & & & & & & & \\
\hline$[8]$ & 2021 & China & educational building & & & $x$ & & & $\mathbf{N}$ & EnergyPlus, Eppy & MATLAB & & & $x$ & & $x$ & $x$ & $x$ & $\mathbf{x}$ & & & & & \\
\hline [14] & 2021 & Malaysia & office building & & & $x$ & $x$ & & $\mathbf{N}$ & Ladybug, Honeybee & Octopus & & & & & & & & & & & & & $x$ \\
\hline [40] & 2021 & Taiwan & office building & $x$ & $x$ & & & & $\mathbf{N}$ & Numerical model & MATLAB & & $x$ & $x$ & & $x$ & & $x$ & $x$ & & & & & \\
\hline [13] & 2021 & Japan & residential building & & & $x$ & $x$ & & $\mathbf{N}$ & Ladybug, Honeybee & Octopus & & $x$ & $x$ & & & & & & $x$ & & & & \\
\hline
\end{tabular}




\section{References}

1. International Energy Agency. The Critical Role of Buildings; International Energy Agency: Paris, France, 2019.

2. Abdou, N.; EL Mghouchi, Y.; Hamdaoui, S.; EL Asri, N.; Mouqallid, M. Multi-objective optimization of passive energy efficiency measures for net-zero energy building in Morocco. Build. Environ. 2021, 204, 108141. [CrossRef]

3. Zou, Y.; Zhan, Q.; Xiang, K. A comprehensive method for optimizing the design of a regular architectural space to improve building performance. Energy Rep. 2021, 7, 981-996. [CrossRef]

4. Machairas, V.; Tsangrassoulis, A.; Axarli, K. Algorithms for optimization of building design: A review. Renew. Sustain. Energy Rev. 2014, 31, 101-112. [CrossRef]

5. Nguyen, A.T.; Reiter, S.; Rigo, P. A review on simulation-based optimization methods applied to building performance analysis. Appl. Energy 2014, 113, 1043-1058. [CrossRef]

6. Ascione, F.; De Masi, R.F.; de Rossi, F.; Ruggiero, S.; Vanoli, G.P. Optimization of building envelope design for nZEBs in Mediterranean climate: Performance analysis of residential case study. Appl. Energy 2016, 183, 938-957. [CrossRef]

7. Carlucci, S.; Cattarin, G.; Causone, F.; Pagliano, L. Multi-objective optimization of a nearly zero-energy building based on thermal and visual discomfort minimization using a non-dominated sorting genetic algorithm (NSGA-II). Energy Build. 2015, 104, 378-394. [CrossRef]

8. Yue, N.; Li, L.; Morandi, A.; Zhao, Y. A metamodel-based multi-objective optimization method to balance thermal comfort and energy efficiency in a campus gymnasium. Energy Build. 2021, 253, 111513. [CrossRef]

9. Fang, K.-T.; Li, R.; Sudjianto, A. Design and Modeling for Computer Experiments; Chapman and Hall/CRC: New York, NY, USA, 2005; ISBN 0429143761.

10. Asadi, E.; Da Silva, M.G.; Antunes, C.H.; Dias, L.; Glicksman, L. Multi-objective optimization for building retrofit: A model using genetic algorithm and artificial neural network and an application. Energy Build. 2014, 81, 444-456. [CrossRef]

11. Magnier, L.; Haghighat, F. Multiobjective optimization of building design using TRNSYS simulations, genetic algorithm, and Artificial Neural Network. Build. Environ. 2010, 45, 739-746. [CrossRef]

12. Zhang, H.; Hewage, K.; Prabatha, T.; Sadiq, R. Life cycle thinking-based energy retrofits evaluation framework for Canadian residences: A Pareto optimization approach. Build. Environ. 2021, 204, 108115. [CrossRef]

13. Wang, J.; Mae, M.; Taniguchi, K.; Cheng, Y.; Yagi, S.; Saito, K. Multi-phase framework for optimization of thermal and daylight performance of residential buildings based on the combination of ventilation and window design. J. Asian Archit. Build. Eng. 2021, 20, 785-805. [CrossRef]

14. Bahdad, A.A.S.; Fadzil, S.F.S.; Onubi, H.O.; BenLasod, S.A. Multi-dimensions optimization for optimum modifications of light-shelves parameters for daylighting and energy efficiency. Int. J. Environ. Sci. Technol. 2021. [CrossRef]

15. Kim, H.; Clayton, M.J. A multi-objective optimization approach for climate-adaptive building envelope design using parametric behavior maps. Build. Environ. 2020, 185, 107292. [CrossRef]

16. Ilbeigi, M.; Ghomeishi, M.; Dehghanbanadaki, A. Prediction and optimization of energy consumption in an office building using artificial neural network and a genetic algorithm. Sustain. Cities Soc. 2020, 61, 102325. [CrossRef]

17. Camporeale, P.E.; Moyano, M.D.P.M.; Czajkowski, J.D. Multi-objective optimisation model: A housing block retrofit in Seville. Energy Build. 2017, 153, 476-484. [CrossRef]

18. Talaei, M.; Mahdavinejad, M.; Azari, R.; Prieto, A.; Sangin, H. Multi-objective optimization of building-integrated microalgae photobioreactors for energy and daylighting performance. J. Build. Eng. 2021, 42, 102832. [CrossRef]

19. Zhuang, D.; Zhang, X.; Lu, Y.; Wang, C.; Jin, X.; Zhou, X.; Shi, X. A performance data integrated BIM framework for building life-cycle energy efficiency and environmental optimization design. Autom. Constr. 2021, 127, 103712. [CrossRef]

20. Zani, A.; Tagliabue, L.C.; Poli, T.; Ciribini, A.L.C.; De Angelis, E.; Manfren, M. Occupancy Profile Variation Analyzed through Generative Modelling to Control Building Energy Behavior. Procedia Eng. 2017, 180, 1495-1505. [CrossRef]

21. Lobaccaro, G.; Wiberg, A.H.; Ceci, G.; Manni, M.; Lolli, N.; Berardi, U. Parametric design to minimize the embodied GHG emissions in a ZEB. Energy Build. 2018, 167, 106-123. [CrossRef]

22. Pilechiha, P.; Mahdavinejad, M.; Pour Rahimian, F.; Carnemolla, P.; Seyedzadeh, S. Multi-objective optimisation framework for designing office windows: Quality of view, daylight and energy efficiency. Appl. Energy 2020, 261, 114356. [CrossRef]

23. Negendahl, K.; Nielsen, T.R. Building energy optimization in the early design stages: A simplified method. Energy Build. 2015, 105, 88-99. [CrossRef]

24. Carreras, J.; Pozo, C.; Boer, D.; Guillén-Gosálbez, G.; Caballero, J.A.; Ruiz-Femenia, R.; Jiménez, L. Systematic approach for the life cycle multi-objective optimization of buildings combining objective reduction and surrogate modeling. Energy Build. 2016, 130, 506-518. [CrossRef]

25. Harkouss, F.; Fardoun, F.; Biwole, P.H. Passive design optimization of low energy buildings in different climates. Energy 2018, 165, 591-613. [CrossRef]

26. Pajek, L.; Košir, M. Strategy for achieving long-term energy efficiency of European single-family buildings through passive climate adaptation. Appl. Energy 2021, 297, 117116. [CrossRef]

27. Rahmani Asl, M.; Zarrinmehr, S.; Bergin, M.; Yan, W. BPOpt: A framework for BIM-based performance optimization. Energy Build. 2015, 108, 401-412. [CrossRef] 
28. Chen, Z.; Hammad, A.W.A.; Kamardeen, I.; Akbarnezhad, A. Optimising Embodied Energy and Thermal Performance of Thermal Insulation in Building Envelopes via an Automated Building Information Modelling (BIM) Tool. Buildings 2020, 10, 218. [CrossRef]

29. Chen, Z.; Hammad, A.W.A.; Kamardeen, I.; Haddad, A. Optimising Window Design on Residential Building Facades by Considering Heat Transfer and Natural Lighting in Nontropical Regions of Australia. Buildings 2020, 10, 206. [CrossRef]

30. Wu, M.H.; Ng, T.S.; Skitmore, M.R. Sustainable building envelope design by considering energy cost and occupant satisfaction. Energy Sustain. Dev. 2016, 31, 118-129. [CrossRef]

31. Gilles, F.; Bernard, S.; Ioannis, A.; Simon, R. Decision-making based on network visualization applied to building life cycle optimization. Sustain. Cities Soc. 2017, 35, 565-573. [CrossRef]

32. de Almeida Rocha, A.P.; Reynoso-Meza, G.; Oliveira, R.C.L.F.; Mendes, N. A pixel counting based method for designing shading devices in buildings considering energy efficiency, daylight use and fading protection. Appl. Energy 2020, 262, 114497. [CrossRef]

33. Islam, H.; Jollands, M.; Setunge, S.; Bhuiyan, M.A. Optimization approach of balancing life cycle cost and environmental impacts on residential building design. Energy Build. 2015, 87, 282-292. [CrossRef]

34. Yong, Z.; Li-juan, Y.; Qian, Z.; Xiao-yan, S. Multi-objective optimization of building energy performance using a particle swarm optimizer with less control parameters. J. Build. Eng. 2020, 32, 101505. [CrossRef]

35. Ghaderian, M.; Veysi, F. Multi-objective optimization of energy efficiency and thermal comfort in an existing office building using NSGA-II with fitness approximation: A case study. J. Build. Eng. 2021, 41, 102440. [CrossRef]

36. Ascione, F.; Bianco, N.; Mauro, G.M.; Napolitano, D.F.; Vanoli, G.P. Optimization of solar energy exploitation for a neighborhood towards nearly zero energy buildings. In Proceedings of the 2020 5th International Conference on Smart and Sustainable Technologies (SpliTech), Split, Croatia, 23-26 September 2020; pp. 1-7.

37. Karatas, A.; El-Rayes, K. Optimizing tradeoffs among housing sustainability objectives. Autom. Constr. 2015, 53, 83-94. [CrossRef]

38. Ascione, F.; Bianco, N.; Mauro, G.M.; Napolitano, D.F.; Vanoli, G.P. A Multi-Criteria Approach to Achieve Constrained CostOptimal Energy Retrofits of Buildings by Mitigating Climate Change and Urban Overheating. Climate 2018, 6, 37. [CrossRef]

39. Chang, S.; Castro-Lacouture, D.; Yamagata, Y. Decision support for retrofitting building envelopes using multi-objective optimization under uncertainties. J. Build. Eng. 2020, 32, 101413. [CrossRef]

40. Lin, Y.H.; Lin, M.D.; Tsai, K.T.; Deng, M.J.; Ishii, H. Multi-objective optimization design of green building envelopes and air conditioning systems for energy conservation and $\mathrm{CO}_{2}$ emission reduction. Sustain. Cities Soc. 2021, 64, 102555. [CrossRef]

41. Ferreira, A.C.; Silva, A.; Teixeira, J.C.; Teixeira, S. Multi-Objective Optimization of Solar Thermal Systems Applied to Portuguese Dwellings. Energies 2020, 13, 6739. [CrossRef]

42. Futrell, B.J.; Ozelkan, E.C.; Brentrup, D. Bi-objective optimization of building enclosure design for thermal and lighting performance. Build. Environ. 2015, 92, 591-602. [CrossRef]

43. Ameur, M.; Kharbouch, Y.; Mimet, A. Optimization of passive design features for a naturally ventilated residential building according to the bioclimatic architecture concept and considering the northern Morocco climate. Build. Simul. 2020, 13, 677-689. [CrossRef]

44. Ferrara, M.; Sirombo, E.; Fabrizio, E. Automated optimization for the integrated design process: The energy, thermal and visual comfort nexus. Energy Build. 2018, 168, 413-427. [CrossRef]

45. Si, B.; Wang, J.; Yao, X.; Shi, X.; Jin, X.; Zhou, X. Multi-objective optimization design of a complex building based on an artificial neural network and performance evaluation of algorithms. Adv. Eng. Inform. 2019, 40, 93-109. [CrossRef]

46. Giouri, E.D.; Tenpierik, M.; Turrin, M. Zero energy potential of a high-rise office building in a Mediterranean climate: Using multi-objective optimization to understand the impact of design decisions towards zero-energy high-rise buildings. Energy Build. 2020, 209, 109666. [CrossRef]

47. Stamatakis, A.; Mandalaki, M.; Tsoutsos, T. Multi-criteria analysis for PV integrated in shading devices for Mediterranean region Energy Build. 2016, 117, 128-137. [CrossRef]

48. Amer, M.; Hamdy, M.; Wortmann, T.; Mustafa, A.; Attia, S. Methodology for design decision support of cost-optimal zero-energy lightweight construction. Energy Build. 2020, 223, 110170. [CrossRef]

49. Bayoumi, M.; Fink, D. Maximizing the performance of an energy generating façade in terms of energy saving strategies. Renew. Energy 2014, 64, 294-305. [CrossRef]

50. Hiyama, K.; Wen, L. Rapid response surface creation method to optimize window geometry using dynamic daylighting simulation and energy simulation. Energy Build. 2015, 107, 417-423. [CrossRef]

51. Harmathy, N.; Magyar, Z.; Folić, R. Multi-criterion optimization of building envelope in the function of indoor illumination quality towards overall energy performance improvement. Energy 2016, 114, 302-317. [CrossRef]

52. Mangkuto, R.A.; Rohmah, M.; Asri, A.D. Design optimisation for window size, orientation, and wall reflectance with regard to various daylight metrics and lighting energy demand: A case study of buildings in the tropics. Appl. Energy 2016, 164, 211-219. [CrossRef]

53. Utkucu, D.; Sözer, H. An evaluation process for natural ventilation using a scenario-based multi-criteria and multi-interaction analysis. Energy Rep. 2020, 6, 644-661. [CrossRef]

54. Mukkavaara, J.; Sandberg, M. Architectural Design Exploration Using Generative Design: Framework Development and Case Study of a Residential Block. Buildings 2020, 10, 201. [CrossRef] 
55. Carriço de Lima Montenegro Duarte, J.G.; Ramos Zemero, B.; Dias Barreto de Souza, A.C.; de Lima Tostes, M.E.; Holanda Bezerra, U. Building Information Modeling approach to optimize energy efficiency in educational buildings. J. Build. Eng. 2021, $43,102587$. [CrossRef]

56. Croitoru, C.; Nastase, I.; Sandu, M.; Lungu, C. Multi-criteria Design and Impact on Energy Consumption of a Residential House-A Parametric Study. Energy Procedia 2016, 85, 141-148. [CrossRef]

57. Allouhi, A. Solar PV integration in commercial buildings for self-consumption based on life-cycle economic/environmental multi-objective optimization. J. Clean. Prod. 2020, 270, 122375. [CrossRef]

58. Zou, Y.; Lou, S.; Xia, D.; Lun, I.Y.F.; Yin, J. Multi-objective building design optimization considering the effects of long-term climate change. J. Build. Eng. 2021, 44, 102904. [CrossRef]

59. Pavičević, M.; Mangipinto, A.; Nijs, W.; Lombardi, F.; Kavvadias, K.; Jiménez Navarro, J.P.; Colombo, E.; Quoilin, S. The potential of sector coupling in future European energy systems: Soft linking between the Dispa-SET and JRC-EU-TIMES models. Appl. Energy 2020, 267, 115100. [CrossRef]

60. Ascione, F.; Bianco, N.; Mauro, G.M.; Napolitano, D.F.; Vanoli, G.P. Weather-data-based control of space heating operation via multi-objective optimization: Application to Italian residential buildings. Appl. Therm. Eng. 2019, 163, 114384. [CrossRef]

61. Xu, W.; Chong, A.; Karaguzel, O.T.; Lam, K.P. Improving evolutionary algorithm performance for integer type multi-objective building system design optimization. Energy Build. 2016, 127, 714-729. [CrossRef]

62. Méndez Echenagucia, T.; Capozzoli, A.; Cascone, Y.; Sassone, M. The early design stage of a building envelope: Multi-objective search through heating, cooling and lighting energy performance analysis. Appl. Energy 2015, 154, 577-591. [CrossRef]

63. Shao, Y.; Geyer, P.; Lang, W. Integrating requirement analysis and multi-objective optimization for office building energy retrofit strategies. Energy Build. 2014, 82, 356-368. [CrossRef]

64. Azari, R.; Garshasbi, S.; Amini, P.; Rashed-Ali, H.; Mohammadi, Y. Multi-objective optimization of building envelope design for life cycle environmental performance. Energy Build. 2016, 126, 524-534. [CrossRef]

65. Kasinalis, C.; Loonen, R.C.G.M.; Cóstola, D.; Hensen, J.L.M. Framework for assessing the performance potential of seasonally adaptable facades using multi-objective optimization. Energy Build. 2014, 79, 106-113. [CrossRef]

66. Brownlee, A.E.I.; Wright, J.A. Constrained, mixed-integer and multi-objective optimisation of building designs by NSGA-II with fitness approximation. Appl. Soft Comput. 2015, 33, 114-126. [CrossRef]

67. Lu, Y.; Wang, S.; Zhao, Y.; Yan, C. Renewable energy system optimization of low/zero energy buildings using single-objective and multi-objective optimization methods. Energy Build. 2015, 89, 61-75. [CrossRef]

68. Yu, W.; Li, B.; Jia, H.; Zhang, M.; Wang, D. Application of multi-objective genetic algorithm to optimize energy efficiency and thermal comfort in building design. Energy Build. 2015, 88, 135-143. [CrossRef]

69. Lobaccaro, G.; Chatzichristos, S.; Leon, V.A. Solar Optimization of Housing Development. Energy Procedia 2016, 91, 868-875. [CrossRef]

70. Bre, F.; Silva, A.S.; Ghisi, E.; Fachinotti, V.D. Residential building design optimisation using sensitivity analysis and genetic algorithm. Energy Build. 2016, 133, 853-866. [CrossRef]

71. Chen, X.; Yang, H.; Sun, K. A holistic passive design approach to optimize indoor environmental quality of a typical residential building in Hong Kong. Energy 2016, 113, 267-281. [CrossRef]

72. Delgarm, N.; Sajadi, B.; Delgarm, S.; Kowsary, F. A novel approach for the simulation-based optimization of the buildings energy consumption using NSGA-II: Case study in Iran. Energy Build. 2016, 127, 552-560. [CrossRef]

73. Zhang, L.; Zhang, L.; Wang, Y. Shape optimization of free-form buildings based on solar radiation gain and space efficiency using a multi-objective genetic algorithm in the severe cold zones of China. Sol. Energy 2016, 132, 38-50. [CrossRef]

74. Delgarm, N.; Sajadi, B.; Kowsary, F.; Delgarm, S. Multi-objective optimization of the building energy performance: A simulationbased approach by means of particle swarm optimization (PSO). Appl. Energy 2016, 170, 293-303. [CrossRef]

75. Figueiredo, A.; Kämpf, J.; Vicente, R. Passive house optimization for Portugal: Overheating evaluation and energy performance. Energy Build. 2016, 118, 181-196. [CrossRef]

76. Konis, K.; Gamas, A.; Kensek, K. Passive performance and building form: An optimization framework for early-stage design support. Sol. Energy 2016, 125, 161-179. [CrossRef]

77. Bre, F.; Fachinotti, V.D. A computational multi-objective optimization method to improve energy efficiency and thermal comfort in dwellings. Energy Build. 2017, 154, 283-294. [CrossRef]

78. Chen, X.; Yang, H. A multi-stage optimization of passively designed high-rise residential buildings in multiple building operation scenarios. Appl. Energy 2017, 206, 541-557. [CrossRef]

79. Bonamente, E.; Brunelli, C.; Castellani, F.; Garinei, A.; Biondi, L.; Marconi, M.; Piccioni, E. A life-cycle approach for multi-objective optimisation in building design: Methodology and application to a case study. Civ. Eng. Environ. Syst. 2018, 35, 158-179. [CrossRef]

80. Gou, S.; Nik, V.M.; Scartezzini, J.L.; Zhao, Q.; Li, Z. Passive design optimization of newly-built residential buildings in Shanghai for improving indoor thermal comfort while reducing building energy demand. Energy Build. 2018, 169, 484-506. [CrossRef]

81. Grygierek, K.; Ferdyn-Grygierek, J. Multi-Objective Optimization of the Envelope of Building with Natural Ventilation. Energies 2018, 11, 1383. [CrossRef]

82. Lin, Y.; Yang, W. Application of Multi-Objective Genetic Algorithm Based Simulation for Cost-Effective Building Energy Efficiency Design and Thermal Comfort Improvement. Front. Energy Res. 2018, 6, 25. [CrossRef] 
83. Chen, X.; Yang, H. Integrated energy performance optimization of a passively designed high-rise residential building in different climatic zones of China. Appl. Energy 2018, 215, 145-158. [CrossRef]

84. Harkouss, F.; Fardoun, F.; Biwole, P.H. Multi-objective optimization methodology for net zero energy buildings. J. Build. Eng. 2018, 16, 57-71. [CrossRef]

85. Lin, Y.; Zhou, S.; Yang, W.; Li, C.-Q. Design Optimization Considering Variable Thermal Mass, Insulation, Absorptance of Solar Radiation, and Glazing Ratio Using a Prediction Model and Genetic Algorithm. Sustainability 2018, 10, 336. [CrossRef]

86. Wu, W.; Guo, J.; Li, J.; Hou, H.; Meng, Q.; Wang, W. A multi-objective optimization design method in zero energy building study: A case study concerning small mass buildings in cold district of China. Energy Build. 2018, 158, 1613-1624. [CrossRef]

87. Shakouri, H.; Rahmani, M.; Hosseinzadeh, M.; Kazemi, A. Multi-objective optimization-simulation model to improve the buildings' design specification in different climate zones of Iran. Sustain. Cities Soc. 2018, 40, 394-415. [CrossRef]

88. Chen, K.W.; Janssen, P.; Schlueter, A. Multi-objective optimisation of building form, envelope and cooling system for improved building energy performance. Autom. Constr. 2018, 94, 449-457. [CrossRef]

89. Yang, D.; Ren, S.; Turrin, M.; Sariyildiz, S.; Sun, Y. Multi-disciplinary and multi-objective optimization problem re-formulation in computational design exploration: A case of conceptual sports building design. Autom. Constr. 2018, 92, 242-269. [CrossRef]

90. Lee, J. Multi-objective optimization case study with active and passive design in building engineering. Struct. Multidiscip. Optim. 2019, 59, 507-519. [CrossRef]

91. Salandin, A.; Soler, D.; Bevivino, M. An Integer Linear Programming approach to minimize the cost of the refurbishment of a façade to improve the energy efficiency of a building. Math. Methods Appl. Sci. 2020, 43, 8067-8088. [CrossRef]

92. Sarkar, A.; Bardhan, R. Optimal interior design for naturally ventilated low-income housing: A design-route for environmental quality and cooling energy saving. Adv. Build. Energy Res. 2020, 14, 494-526. [CrossRef]

93. Gagnon, R.; Gosselin, L.; Armand Decker, S. Performance of a sequential versus holistic building design approach using multi-objective optimization. J. Build. Eng. 2019, 26, 100883. [CrossRef]

94. Lan, L.; Wood, K.L.; Yuen, C. A holistic design approach for residential net-zero energy buildings: A case study in Singapore Sustain. Cities Soc. 2019, 50, 101672. [CrossRef]

95. Taveres-Cachat, E.; Lobaccaro, G.; Goia, F.; Chaudhary, G. A methodology to improve the performance of PV integrated shading devices using multi-objective optimization. Appl. Energy 2019, 247, 731-744. [CrossRef]

96. García Kerdan, I.; Morillón Gálvez, D.; Sousa, G.; Suárez de la Fuente, S.; Silva, R.; Hawkes, A. Thermodynamic and thermal comfort optimisation of a coastal social house considering the influence of the thermal breeze. Build. Environ. 2019, 155, 224-246. [CrossRef]

97. Waibel, C.; Evins, R.; Carmeliet, J. Co-simulation and optimization of building geometry and multi-energy systems: Interdependencies in energy supply, energy demand and solar potentials. Appl. Energy 2019, 242, 1661-1682. [CrossRef]

98. Hong, T.; Kim, J.; Lee, M. A multi-objective optimization model for determining the building design and occupant behaviors based on energy, economic, and environmental performance. Energy 2019, 174, 823-834. [CrossRef]

99. Ascione, F.; Bianco, N.; Maria Mauro, G.; Napolitano, D.F. Building envelope design: Multi-objective optimization to minimize energy consumption, global cost and thermal discomfort. Application to different Italian climatic zones. Energy 2019, 174, 359-374. [CrossRef]

100. Ascione, F.; Bianco, N.; Mauro, G.M.; Vanoli, G.P. A new comprehensive framework for the multi-objective optimization of building energy design: Harlequin. Appl. Energy 2019, 241, 331-361. [CrossRef]

101. Zhai, Y.; Wang, Y.; Huang, Y.; Meng, X. A multi-objective optimization methodology for window design considering energy consumption, thermal environment and visual performance. Renew. Energy 2019, 134, 1190-1199. [CrossRef]

102. Shadram, F.; Mukkavaara, J. Exploring the effects of several energy efficiency measures on the embodied/operational energy trade-off: A case study of swedish residential buildings. Energy Build. 2019, 183, 283-296. [CrossRef]

103. Si, Y.; Yu, J.; Wang, N.; Ding, X.; Yuan, L. Research on evaluation and optimization of sustainable indoor environment of public buildings in Xi'an in summer. Intell. Build. Int. 2020, 12, 271-283. [CrossRef]

104. Wahid, F.; Fayaz, M.; Aljarbouh, A.; Mir, M.; Aamir, M. Imran Energy Consumption Optimization and User Comfort Maximization in Smart Buildings Using a Hybrid of the Firefly and Genetic Algorithms. Energies 2020, 13, 4363. [CrossRef]

105. Manni, M.; Lobaccaro, G.; Lolli, N.; Bohne, R.A. Parametric design to maximize solar irradiation and minimize the embodied GHG emissions for a ZEB in nordic and mediterranean climate zones. Energies 2020, 13, 4981. [CrossRef]

106. Grygierek, K.; Sarna, I. Impact of Passive Cooling on Thermal Comfort in a Single-Family Building for Current and Future Climate Conditions. Energies 2020, 13, 5332. [CrossRef]

107. Guo, R.; Heiselberg, P.; Hu, Y.; Zhang, C.; Vasilevskis, S. Optimization of night ventilation performance in office buildings in a cold climate. Energy Build. 2020, 225, 110319. [CrossRef]

108. Al-Saadi, S.N.; Al-Jabri, K.S. Optimization of envelope design for housing in hot climates using a genetic algorithm (GA) computational approach. J. Build. Eng. 2020, 32, 101712. [CrossRef]

109. Seong, N.-C.; Kim, J.-H.; Choi, W. Adjustment of Multiple Variables for Optimal Control of Building Energy Performance via a Genetic Algorithm. Buildings 2020, 10, 195. [CrossRef]

110. Figueiredo, A.; Vicente, R.; Oliveira, R.; Rodrigues, F.; Samagaio, A. Multiscale Modelling Approach Targeting Optimisation of PCM into Constructive Solutions for Overheating Mitigation in Buildings. Appl. Sci. 2020, 10, 8009. [CrossRef] 
111. Vishwamitra, O.; Nidhish, S. Multi-objective optimization of the energy performance of residential buildings in tropical climates. In Proceedings of the 2020 3rd International Conference on Emerging Trends in Electrical, Electronic and Communications Engineering (ELECOM), Balaclava, Mauritius, 25-27 November 2020; pp. 240-243.

112. Bagheri-Esfeh, H.; Safikhani, H.; Motahar, S. Multi-objective optimization of cooling and heating loads in residential buildings integrated with phase change materials using the artificial neural network and genetic algorithm. J. Energy Storage 2020, $32,101772$. [CrossRef]

113. Ciardiello, A.; Rosso, F.; Dell'Olmo, J.; Ciancio, V.; Ferrero, M.; Salata, F. Multi-objective approach to the optimization of shape and envelope in building energy design. Appl. Energy 2020, 280, 115984. [CrossRef]

114. Li, Y.; Nord, N.; Zhang, N.; Zhou, C. An ANN-based optimization approach of building energy systems: Case study of swimming pool. J. Clean. Prod. 2020, 277, 124029. [CrossRef]

115. Yılmaz, Y.; Yılmaz, B.Ç. A weighted multi-objective optimisation approach to improve based facade aperture sizes in terms of energy, thermal comfort and daylight usage. J. Build. Phys. 2020, 44, 435-460. [CrossRef]

116. Wang, R.; Lu, S.; Feng, W.; Zhai, X.; Li, X. Sustainable framework for buildings in cold regions of China considering life cycle cost and environmental impact as well as thermal comfort. Energy Rep. 2020, 6, 3036-3050. [CrossRef]

117. Bakmohammadi, P.; Noorzai, E. Optimization of the design of the primary school classrooms in terms of energy and daylight performance considering occupants' thermal and visual comfort. Energy Rep. 2020, 6, 1590-1607. [CrossRef]

118. Li, Z.; Genovese, P.V.; Zhao, Y. Study on Multi-Objective Optimization-Based Climate Responsive Design of Residential Building. Algorithms 2020, 13, 238. [CrossRef]

119. Zhao, J.; Du, Y. Multi-objective optimization design for windows and shading configuration considering energy consumption and thermal comfort: A case study for office building in different climatic regions of China. Sol. Energy 2020, 206, 997-1017. [CrossRef]

120. Yeom, S.; Kim, H.; Hong, T.; Lee, M. Determining the optimal window size of office buildings considering the workers' task performance and the building's energy consumption. Build. Environ. 2020, 177, 106872. [CrossRef]

121. Settino, J.; Carpino, C.; Perrella, S.; Arcuri, N. Multi-Objective Analysis of a Fixed Solar Shading System in Different Climatic Areas. Energies 2020, 13, 3249. [CrossRef]

122. Wang, R.; Lu, S.; Feng, W. Impact of adjustment strategies on building design process in different climates oriented by multiple performance. Appl. Energy 2020, 266, 114822. [CrossRef]

123. Naderi, E.; Sajadi, B.; Behabadi, M.A.; Naderi, E. Multi-objective simulation-based optimization of controlled blind specifications to reduce energy consumption, and thermal and visual discomfort: Case studies in Iran. Build. Environ. 2020, 169, 106570. [CrossRef]

124. Bre, F.; Roman, N.; Fachinotti, V.D. An efficient metamodel-based method to carry out multi-objective building performance optimizations. Energy Build. 2020, 206, 109576. [CrossRef]

125. Lakhdari, K.; Sriti, L.; Painter, B. Parametric optimization of daylight, thermal and energy performance of middle school classrooms, case of hot and dry regions. Build. Environ. 2021, 204, 108173. [CrossRef]

126. Dong, Y.; Sun, C.; Han, Y.; Liu, Q. Intelligent optimization: A novel framework to automatize multi-objective optimization of building daylighting and energy performances. J. Build. Eng. 2021, 43, 102804. [CrossRef]

127. Luo, X.J.; Oyedele, L.O. A data-driven life-cycle optimisation approach for building retrofitting: A comprehensive assessment on economy, energy and environment. J. Build. Eng. 2021, 43, 102934. [CrossRef]

128. Hong, X.; Shi, F.; Wang, S.; Yang, X.; Yang, Y. Multi-objective optimization of thermochromic glazing based on daylight and energy performance evaluation. Build. Simul. 2021, 14, 1685-1695. [CrossRef]

129. Zhu, N.; Liu, X.; Dong, Q.; Rodriguez, D. Optimization of zero-energy building by multi-criteria optimization method: A case study. J. Build. Eng. 2021, 44, 102969. [CrossRef]

130. Bahdad, A.A.S.; Fadzil, S.F.S.; Onubi, H.O.; BenLasod, S.A. Sensitivity analysis linked to multi-objective optimization for adjustments of light-shelves design parameters in response to visual comfort and thermal energy performance. J. Build. Eng. 2021, 44, 102996. [CrossRef]

131. Paul, R.; Dalui, S. Shape Optimization to Reduce Wind Pressure on the Surfaces of a Rectangular Building with Horizontal Limbs. Period. Polytech. Civ. Eng. 2021, 65, 134-149. [CrossRef]

132. Li, Q.; Zhang, L.; Zhang, L.; Wu, X. Optimizing energy efficiency and thermal comfort in building green retrofit. Energy 2021, 237, 121509. [CrossRef]

133. Ascione, F.; Bianco, N.; Mauro, G.M.; Napolitano, D.F.; Vanoli, G.P. Comprehensive analysis to drive the energy retrofit of a neighborhood by optimizing the solar energy exploitation-An Italian case study. J. Clean. Prod. 2021, 314, 127998. [CrossRef]

134. Acar, U.; Kaska, O.; Tokgoz, N. Multi-objective optimization of building envelope components at the preliminary design stage for residential buildings in Turkey. J. Build. Eng. 2021, 42, 102499. [CrossRef]

135. Taylor, M.; Brown, N.C.; Rim, D. Optimizing thermal comfort and energy use for learning environments. Energy Build. 2021, 248, 111181. [CrossRef]

136. Huang, L.; Fan, C.; Zhai, Z. A graphical multi-objective performance evaluation method with architect-friendly mode. Front. Archit. Res. 2021, 10, 420-431. [CrossRef]

137. Wang, S.; Yi, Y.K.; Liu, N. Multi-objective optimization (MOO) for high-rise residential buildings' layout centered on daylight, visual, and outdoor thermal metrics in China. Build. Environ. 2021, 205, 108263. [CrossRef] 
138. Vukadinović, A.; Radosavljević, J.; Đorđević, A.; Protić, M.; Petrović, N. Multi-objective optimization of energy performance for a detached residential building with a sunspace using the NSGA-II genetic algorithm. Sol. Energy 2021, 224, 1426-1444. [CrossRef]

139. Lin, Y.; Zhong, S.; Yang, W.; Hao, X.; Li, C.Q. Multi-objective design optimization on building integrated photovoltaic with Trombe wall and phase change material based on life cycle cost and thermal comfort. Sustain. Energy Technol. Assess. 2021, 46, 101277. [CrossRef]

140. Mashaly, I.A.; Garcia-Hansen, V.; Cholette, M.E.; Isoardi, G. A daylight-oriented multi-objective optimisation of complex fenestration systems. Build. Environ. 2021, 197, 107828. [CrossRef]

141. Vettorazzi, E.; Figueiredo, A.; Rebelo, F.; Vicente, R.; Grala da Cunha, E. Optimization of the passive house concept for residential buildings in the South-Brazilian region. Energy Build. 2021, 240, 110871. [CrossRef]

142. D'Agostino, D.; D'Agostino, P.; Minelli, F.; Minichiello, F. Proposal of a new automated workflow for the computational performance-driven design optimization of building energy need and construction cost. Energy Build. 2021, $239,110857$. [CrossRef]

143. Chen, B.; Liu, Q.; Chen, H.; Wang, L.; Deng, T.; Zhang, L.; Wu, X. Multiobjective optimization of building energy consumption based on BIM-DB and LSSVM-NSGA-II. J. Clean. Prod. 2021, 294, 126153. [CrossRef]

144. Abbasi, S.; Noorzai, E. The BIM-Based multi-optimization approach in order to determine the trade-off between embodied and operation energy focused on renewable energy use. J. Clean. Prod. 2021, 281, 125359. [CrossRef]

145. Naji, S.; Aye, L.; Noguchi, M. Multi-objective optimisations of envelope components for a prefabricated house in six climate zones. Appl. Energy 2021, 282, 116012. [CrossRef]

146. Hammad, A.W.A.; Figueiredo, K.; Rosa, A.C.; Vazquez, E.; Haddad, A. Enhancing the passive design of buildings: A mixed integer non-linear programming approach for the selection of building materials and construction building systems. Energy Rep. 2021, 7, 8162-8175. [CrossRef]

147. Jung, Y.; Heo, Y.; Lee, H. Multi-objective optimization of the multi-story residential building with passive design strategy in South Korea. Build. Environ. 2021, 203, 108061. [CrossRef]

148. Mukkavaara, J.; Shadram, F. An integrated optimization and sensitivity analysis approach to support the life cycle energy trade-off in building design. Energy Build. 2021, 253, 111529. [CrossRef] 